\title{
$\mathrm{UiO}$ : Det juridiske fakultet
}

\section{Forced marriage as a crime against humanity}

Candidate number: 553

Submission deadline: 25 November 2016

Number of words: 17614 


\section{Abbreviations}

AFRC Armed Forces Revolutionary Council

AJ Appeals Judgment

CDF Civil Defence Forces

CEDAW Convention on the Elimination of all Forms of Discrimination Against Women 1979

cf. compare (confer)

e.g. for example (exempli gratia)

ECCC Extraordinary Chambers in the Courts of Cambodia

ed./eds. $\quad$ editor(s)

et al. and others (et alii)

i.e. that is (id est)

Ibid. in the same place (ibidem)

ICC International Criminal Court

ICCPR International Covenant on Civil and Political Rights 1966

ICJ International Court of Justice

ICL International criminal law

ICTR International Criminal Tribunal for the Prosecution of Persons Responsible for Genocide and Other Serious Violations of International Humanitarian Law Committed in the Territory of Rwanda and Rwandan Citizens responsible for genocide and other such violations committed in the territory of neighbouring States, between 1 January 1994 and 31 December 1994. Adopted by UN Security Council res. S/RES/955.

ICTY International Tribunal for the Prosecution of Persons Responsible for Serious Violations of International Humanitarian Law Committed in the Territory of the Former Yugoslavia since 1991. Adopted by UN Security Council res. S/RES/827.

IMT International Military Tribunal at Nuremberg

LRA Lord's Resistance Army

NGO Non-Governmental Organization

OTP Office of the Prosecutor

p. page 
para./paras. paragraph(s)

perse by itself

RPE Rules of Procedure and Evidence

RUF Revolutionary United Front

SCSL Special Court for Sierra Leone

TJ Trial Judgment

UDHR Universal Declaration of Human Rights 1948

UN United Nations 


\section{Table of Contents}

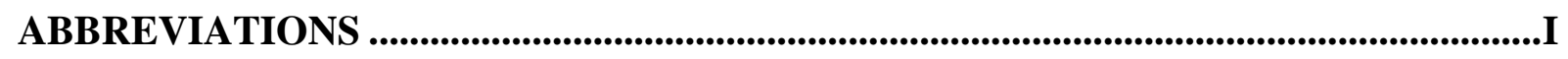

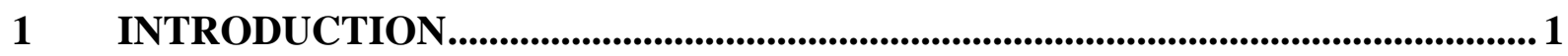

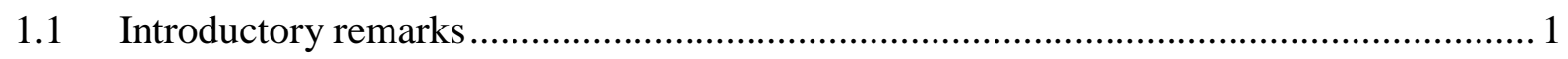

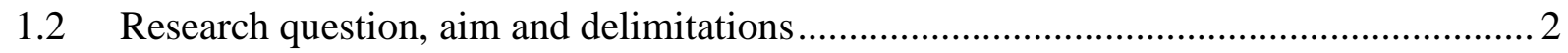

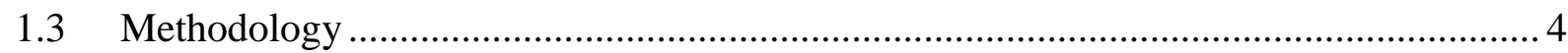

2 FORCED MARRIAGE IN INTERNATIONAL CASE LAW ................................5 5

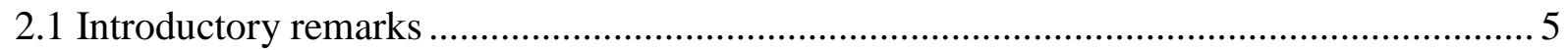

2.2 The Special Court for Sierra Leone ............................................................................ 7

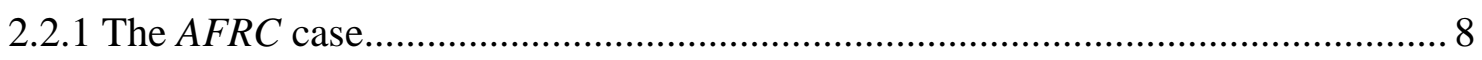

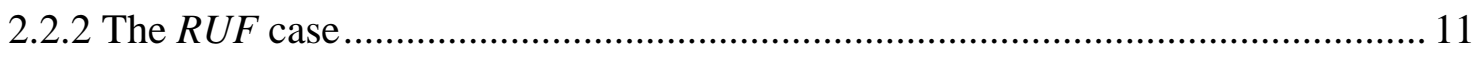

2.3 The Extraordinary Chambers for the Courts of Cambodia .............................................. 13

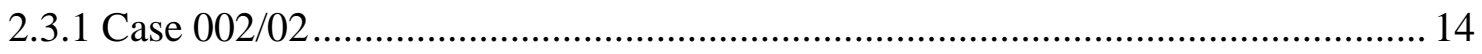

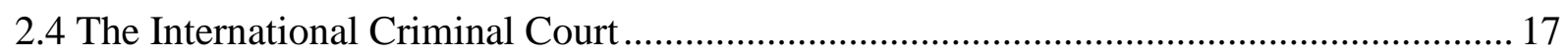

2.4.2 The situation in Uganda and the Ongwen case ................................................ 17

2.5 Is the crime of forced marriage recognized in case law? ............................................... 20

2.5.1 Definitions and elements of the crime ............................................................ 20

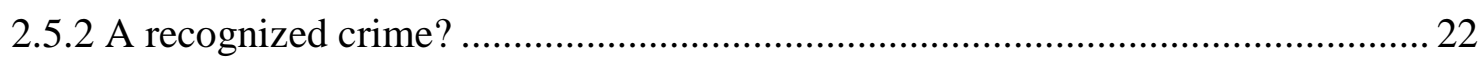

3 FORCED MARRIAGE AS A SEPARATE CRIME AGAINST HUMANITY ..... 28

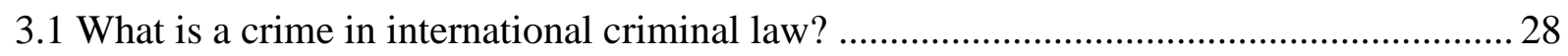

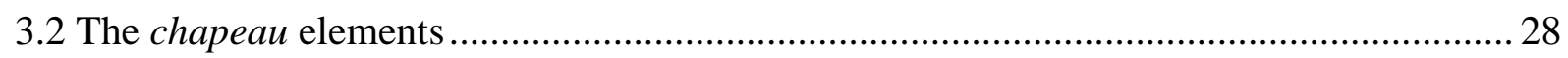

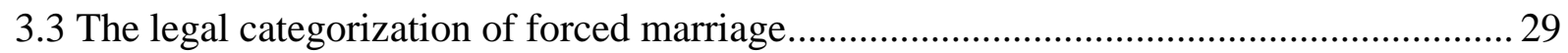

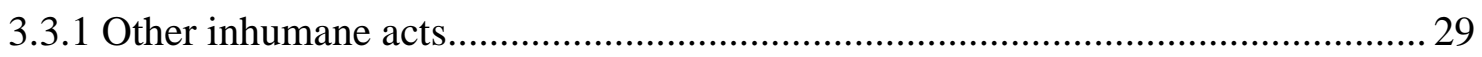

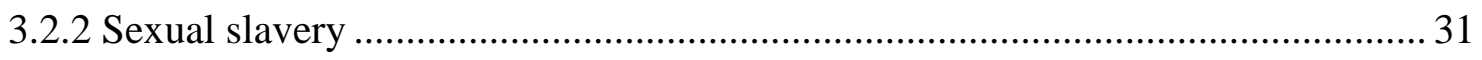

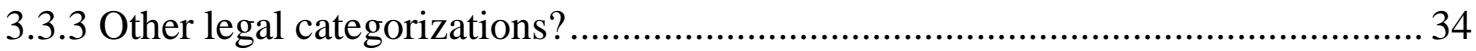

4 CONTRARY TO THE PRINCIPLE OF LEGALITY?....................................... 35

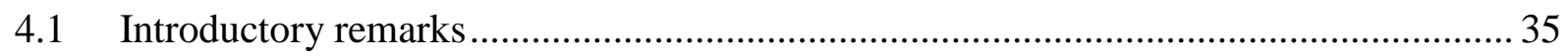

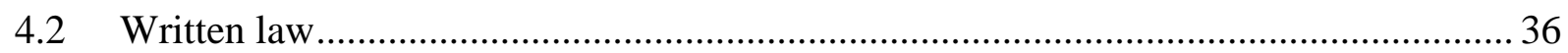

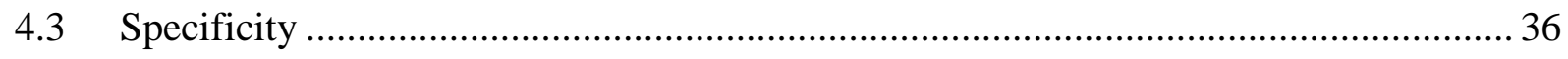

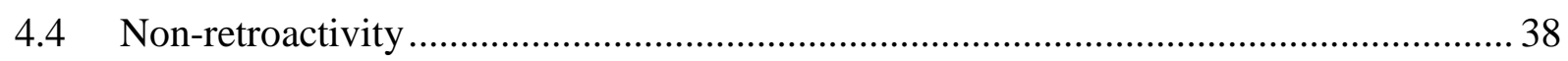

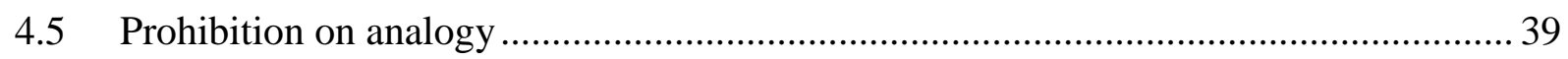

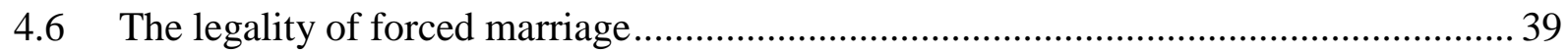


5 THE VIABILITY OF FORCED MARRIAGE AS A SEPARATE CRIME.......... 40

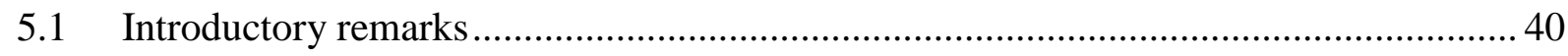

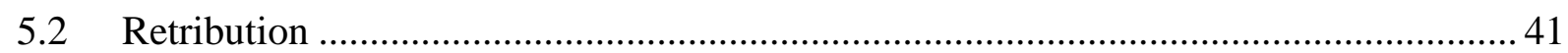

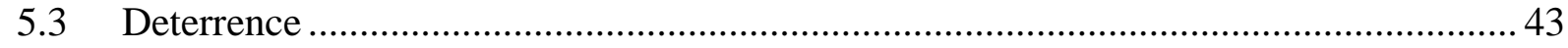

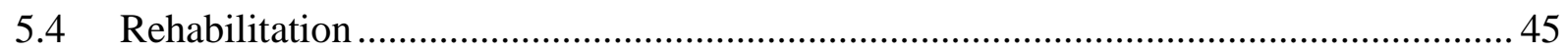

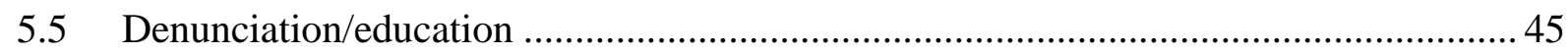

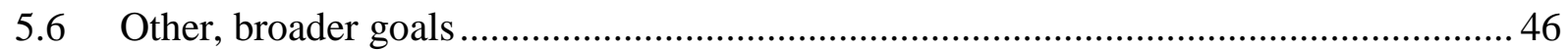

5.7 Concluding remarks on the viability of forced marriage as a separate crime............... 48

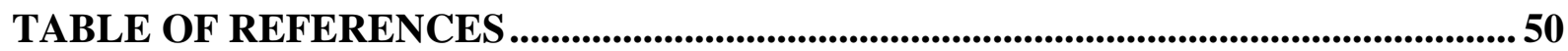




\section{Introduction}

\subsection{Introductory remarks}

Sexual and gender-based crimes directed towards women have existed since the dawn of man. ${ }^{1}$ Crimes against women can serve multiple purposes in the context of war; both as "prizes or incentives to fighting men". ${ }^{2}$ It has been questioned whether "women have been among the 'forgotten' victims of the laws of both international and non-international armed conflict". ${ }^{3}$ In answering this, Chinkin acknowledges that while the silence has been broken and steps towards recognition have been made, women remain largely forgotten. ${ }^{4}$ In the past two decades, we have seen an increased focus on sexual and gender-based violence against women; legal scholars and Non-Governmental Organizations (NGOs) have put such acts on the agenda, and increasingly prosecutors at international criminal tribunals have included sexual and gender-based crimes in their indictments. Furthermore, the role international criminal tribunals have played in developing the law cannot be understated. ${ }^{5}$ One of the newest of such crimes, recognized and developed in international jurisprudence, is "forced marriage"6 as a crime against humanity. ${ }^{7}$

The Report of the UN Secretary-General defined forced marriage as "lacking the free and valid consent of at least one of the parties". ${ }^{8}$ Thus, the key element in forced marriage, one could argue, is the absence of free and full consent. Numerous international human rights instruments and treaties explicitly prohibit forced marriage, see for example Article 16 of the Universal Declaration of Human Rights (UDHR), Article 23 in the International Covenant on Civil and Political Rights (ICCPR), Article 16 the Convention on the Elimination of all Forms of Discrimination Against Women (CEDAW), and Article 1(1) in the Convention on Consent to Marriage, Minimum age for Marriage and Registration for Marriage (CCM). However,

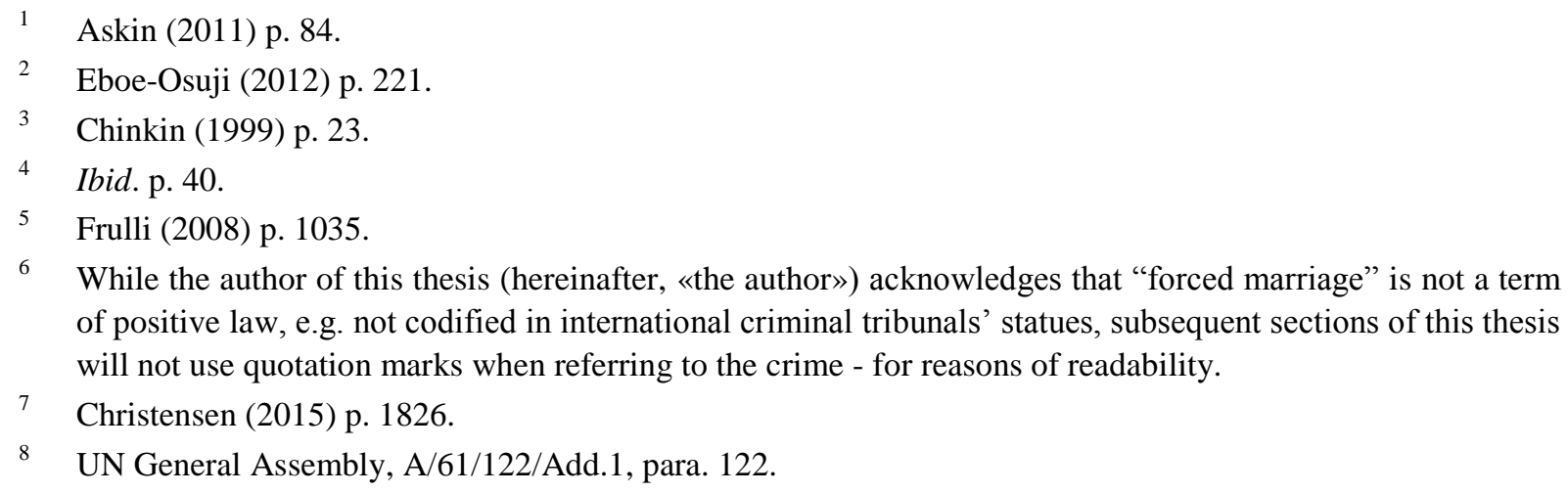
of positive law, e.g. not codified in international criminal tribunals' statues, subsequent sections of this thesis will not use quotation marks when referring to the crime - for reasons of readability.

7 Christensen (2015) p. 1826.

8 UN General Assembly, A/61/122/Add.1, para. 122. 
breaches of human rights do not automatically constitute a breach of international criminal law (hereinafter, ICL) and therefore a criminal offence. ${ }^{9}$ This is because human rights primarily put obligations upon the ratifying State - i.e. the State is obliged to ensure the fulfilment of human rights obligations. ${ }^{10}$

Forced marriage is not only an issue of the past; it is prevalent in conflicts around the world today - for example in Nigeria by the Boko Haram ${ }^{11}$ and in areas under control of ISIS. ${ }^{12}$ Despite forced marriage being a prevalent practice around the world, it has not been explicitly criminalized in any of the international criminal tribunals' statutes. When trapped in forced marriages, women will often experience "unimaginable suffering as their most fundamental human rights (...) [are] stripped away through rape, violence, torture, forced pregnancy, and

forced labour". ${ }^{13}$ Other crimes have been reported to accompany forced marriage, including sexual torture, sexual mutilations, forced abortions and being drugged. ${ }^{14}$ These acts show that forced marriage is a multi-layered crime. ${ }^{15}$ It has been argued that although forced marriage causes immense suffering, it is an "overlooked crime". 16

\subsection{Research question, aim and delimitations}

This thesis sets out to answer the following research question: Has international jurisprudence come to a point of recognition of forced marriage as a separate crime against humanity and if so, is it viable?

The thesis will begin with an historical account, by analysing how forced marriage has been, and is being, dealt with by international criminal tribunals: Parts 2.1-2.4 examine cases wherein forced marriage has been indicted as a separate crime, analysing for each case how the crime was defined and the resulting ratio decidendi. Part 2.5.1 contains a comparative

\footnotetext{
$9 \quad$ Frulli (2008) p. 1039.

10 Cryer et al. (2014) p. 13.

11 https://www.washingtonpost.com/world/africa/they-were-freed-from-boko-harams-rape-camps-but-theirnightmare-isnt-over/2016/04/03/dbf2aab0-e54f-11e5-a9ce-681055c7a05f_story.html (last accessed 7 November 2016).

12 https://www.hrw.org/news/2015/04/14/iraq-isis-escapees-describe-systematic-rape (last accessed 7 November 2016).

13 Scharf and Mattler (2005) p. 24.

14 Human Rights Watch (2003) p. 33 and 41.

15 Frulli (2008) p. 1036.

16 Christensen (2015) p. 1845.
} 
summary of how forced marriage has been recognized hitherto in international case law, which lays the framework for the discussion that follows in Part 2.5.2. The discussion in Part 2.5.2 seeks to put the analysis in Parts 2.2.1 - 2.5.1 in a broader context by assessing the extent to which there is agreement in case law about the definition and elements of the crime forced marriage, as well as whether a judicial precedent has been set in international criminal law.

Part 3 is devoted to a theoretical discussion of forced marriage as a separate crime against humanity. General problems of definition, in addition to possible legal categorizations of forced marriage, will be explored. Part 4 will question the legality of forced marriage as a separate crime.

Part 5 discussed the future of forced marriage as a separate crime against humanity. The approach will be teleological, assessing the viability of the crime of forced marriage in light of the general objectives of ICL.

The aim of this thesis is to further the discussion on forced marriage, and at the same time to put it in a broader context, assessing the viability of the crime as a crime of ICL. Much has been written in the legal field on how forced marriage was dealt with by the Special Court for Sierra Leone (SCSL). ${ }^{17}$ What has been lacking, however, is an up-to-date analysis of the case law of the Extraordinary Chambers for the Courts of Cambodia (ECCC) and the International Criminal Court (ICC) that deals with forced marriage. This thesis intends to contribute to filling that gap.

The scope of this thesis will be limited in a number of ways. Firstly, it will only deal with the occurrence of forced marriage during armed conflicts, not in peacetime. Secondly, although the author recognizes the value of a comparative analysis with domestic criminal law, it will, due to limited space, focus on the sphere of international criminal law. ${ }^{18}$ Thirdly, the thesis focuses solely upon forced marriage as a crime against humanity. It has been argued that

17 As examples, see da Silva (2011), Frulli (2008), Goodfellow (2011) and Oosterveld (2007) (2011a and b) (2012) (2014), Thompson (2014).

18 For an overview of countries which have criminalized forced marriage in domestic law, see the Commission of Women of ECOSOC, E/CN.6/2008/4 p. 7-10. 
forced marriage could constitute a crime of genocide. ${ }^{19}$ That being said, international criminal tribunals have dealt with forced marriage exclusively as a crime against humanity and the author has opted to follow that categorization. Finally, the distinction between forced marriage and arranged marriages will not be discussed in detail. This is due to space limitations, and also because the distinction between forced marriage and sexual slavery will highlight general difficulties in separating forced marriage from other crimes against humanity.

\subsection{Methodology}

In being part of the international legal order, ICL "originates from the same legal sources as international law". ${ }^{20}$ It follows from Article 38(1) of the Statute for the International Court of Justice $^{21}$ that these sources include international conventions, international custom and general principles of law as primary means. Subsidiary sources are judicial decisions and teachings from highly qualified scholars. The ICC has listed its own sources of law, in Article 21(1) of the Rome Statute. ${ }^{22}$

One methodical challenge this thesis faces is reflected in its primary focus, namely forced marriage. Forced marriage is a new international crime which has not been codified in any of the criminal tribunals' statutes; rather, it has evolved through jurisprudence. Additionally, few cases deal with forced marriage. Thus, subsidiary legal sources will be the main provider of the arguments in the analysis. Another challenge is that ICL is a relatively new discipline of international law, often characterized by fragmentation and inconsistencies in its law. ${ }^{23}$ Furthermore, ICL does not have a comprehensive criminal code. These issues pervade the topic of forced marriage, complicating a general discussion of the crime. With these challenges in mind, the author guides the reader by discussing forced marriage from the perspective of the past, the present and the future, while critically assessing the evolution of the criminalization of forced marriage.

\footnotetext{
19 O'Sullivan (2011) p. 272.

$20 \quad$ Werle and Jessberger (2014) p. 56.

21 Statute for the International Court of Justice (ICJ).

22 Rome Statute of the International Criminal Court (hereinafter, Rome Statute).

23 Cryer et al. (2014) p. 590.
} 


\section{Forced marriage in international case law}

\subsection{Introductory remarks}

The types of forced marriages that this thesis will focus upon occur in armed conflicts, and are not to be confused with arranged marriages which occur mainly in peacetime. ${ }^{24}$ An arranged marriage can be defined as "a marriage planned and agreed by the families or guardians of the couple concerned". ${ }^{25}$ The involvement and consent of parents or other family members in selecting and approving are paramount in arranged marriages, and these marriages are normally entered into during peacetime. ${ }^{26}$ In the following cases of forced marriage, the spouses did not necessarily enter into a legal marriage. Instead, the perpetrators used force or coercion to impose a marital conjugation. The discussion uses the term "women" which include both adults and minors. Moreover, the author acknowledges that men can also be forced into marriages, as occurred particularly in Cambodia during the Khmer Rouge regime. However, the author nevertheless chooses to focus mainly upon women. Apart from the Khmer Rouge cases, no other reports of men as victims of forced marriage have appeared in international criminal trials; thus, it appears that male victims of forced marriage are the exception rather than the rule.

The Rome Statute ${ }^{27}$ was the first statute to include a comprehensive codification of sexual and gender-based crimes as crimes against humanity. Crimes against humanity are certain acts directed against the civilian population, as part of a widespread or systematic attack. ${ }^{28}$ It has been argued that crimes against humanity are "as old as humanity itself", ${ }^{29}$ however, they were only first criminalized after World War II in the Nuremberg Charter. ${ }^{30}$ Many of the sexual and gender-based crimes that are listed in the Rome Statute were first recognized and developed in the jurisprudence from the International Criminal Tribunals for Rwanda (ICTR)

\footnotetext{
24 Prosecution Expert Bangura in Prosecutor v Brima et al. p. 9.

25 http://www.oxforddictionaries.com/definition/english/arranged-marriage (last accessed 7 November 2016).

26 Prosecution Expert Bangura in Prosecutor v Brima et al. p. 12.

27 Rome Statute Article 7(1)(g).

28 For example Rome Statute Article 7(1).

29 Cryer et al. (2014) p. 229.

30 Article 6(c) in the Nuremberg Charter. Werle and Jessberger (2014) p. 328.
} 
and the former Yugoslavia (ICTY) respectively. ${ }^{31}$ However, forced marriage as a distinct, separate crime against humanity has neither been codified in the Rome Statute nor in any of the other international criminal tribunals' statutes.

Despite the lack of recognition in these statutes, forced marriage has been, or is being, dealt with in a handful of international cases. Legal history was made in 2008 when the Special Court for Sierra Leone (SCSL) Appeals Chamber delivered a ground-breaking judgment, wherein the act of forced marriage as an 'inhumane act' of crime against humanity was explored and recognized for the first time. ${ }^{32}$ The residual clause 'other inhumane acts' in Article 2(i) of the SCSL Statute serves the purpose of criminalizing acts of similar character and gravity as the already explicitly listed crimes against humanity in Article 2(a)-(h). ${ }^{33}$ The Appeals Chamber held that forced marriage is a distinct and unique crime, of the same gravity as other crimes against humanity. ${ }^{34}$ This finding was supported in the second case litigated before the SCSL, namely the RUF trial. ${ }^{35}$ In recent years, indictments containing charges of forced marriage as an 'other inhumane act' have been brought before both the Extraordinary Chambers for the Courts of Cambodia $(\mathrm{ECCC})^{36}$ and the International Criminal Court (ICC). ${ }^{37}$

This Part seeks to provide a legal analysis of forced marriage in international case law. Christensen argues that forced marriage "will likely not gain significant traction as a crime against humanity without clarification of what elements constitute the crime". ${ }^{38}$ In answering the previously outlined research question - has international jurisprudence come to a point of recognition of forced marriage as a separate crime against humanity - subsequent parts of the thesis will ascertain how forced marriage hitherto has been recognized and assess the extent to

31 For example, in Prosecutor v. Akayesu, TJ paras. 732-734 the ICTR found that rape constituted an act of genocide. Similarly, Prosecutor v. Kunarac et al, was the first case which highlighted the criminal responsibility for sexual slavery; TJ para. 542.

32 Prosecutor v. Brima et al. AJ. Oosterveld (2011a) p. 52.

33 Prosecutor v. Brima et al. AJ para. 183.

$34 \quad$ Ibid. para. 200. Haenen (2013) p. 896.

35 Prosecutor $v$ Sesay et al.

36 Prosecutor v. Chea et al.

37 Prosecutor v. Ongwen.

38 Christensen (2015) p. 1826. 
which there is agreement with respect to the elements which have been found to constitute forced marriage. In short; is there a judicial precedent set in international criminal law?

It is important to bear in mind that every international tribunal operates within its own special environment, and that the Statute of each tribunal includes a set of rules applicable only to that particular tribunal. ${ }^{39}$ A short introduction of each tribunal will therefore be presented, together with the context in which the crimes were committed.

\subsection{The Special Court for Sierra Leone}

During the civil war in Sierra Leone in the 1990s, which lasted for more than a decade, rebel groups such as the Revolutionary United Front (RUF) and Armed Forces Revolutionary Council (ARFC), amongst other parties, committed mass atrocities, particularly directed against the civilian population. ${ }^{40}$ Women were notably affected by the armed conflict, which was, inter alia, characterized by sexual and gender-based crimes. ${ }^{41}$ It is estimated that up to 257000 women were victims of sexual violence. ${ }^{42}$

Forced marriage was a widespread practice in Sierra Leone, ${ }^{43}$ whereby women were abducted from their homes and forcibly married to individual rebels as "bush wives". These marriages were not legal in a formal sense, meaning they were not entered into in accordance with domestic or international law. In many cases, women were married to the perpetrators who had killed their family members, before subsequently being abducted. ${ }^{44}$ The prosecution expert witness in the $A F R C$ case, Mrs. Bangura, gave an account of the daily life of a "bush wife"; “A 'bush wife' carried her 'husband's' possessions as they moved from place to place. She also cooked for him, washed his clothes and satisfied him sexually whenever and however he wanted (...). She could be used, and then disposed of as and when her 'husband' wanted". 45

\footnotetext{
39 Cassese (2008) p. 14.

40 da Silva (2011) p. 232-233.

41 Prosecution Expert Bangura in Prosecutor v. Brima et al. p. 8.

42 Physicians for Human Rights (2002) p. 3-4.

43 https://www.hrw.org/news/2001/02/26/sexual-violence-within-sierra-leone-conflict (last accessed 7 November 2016).

44 Haenen (2013) p. 897.

45 Prosecution Expert Bangura in Prosecutor v. Brima et al. p. 14.
} 
In addition to experiencing sexual slavery, including rape, torture and forced labour, the women faced other horrific acts such as forced pregnancy, forced abortion and being drugged. ${ }^{46}$ In sum, the perpetrators exercised total control over the women's autonomy, including their movement and sexuality.

The hybrid tribunal, SCSL, was established in an agreement between the UN and the Government of Sierra Leone, ${ }^{47}$ with the purpose of prosecuting the most responsible persons for serious violations of international humanitarian law and Sierra Leonean law committed in the territory of Sierra Leone since 30 November $1996 .{ }^{48}$ The Statute, ${ }^{49}$ together with its Rules of Procedure and Evidence, ${ }^{50}$ are the governing documents of the Court. The Court has ratione materiae jurisdiction over certain international crimes ${ }^{51}$ and certain crimes under Sierra Leonean law. ${ }^{52}$ Two cases at the SCSL considered the crime of forced marriage, the AFRC case $^{53}$ and the $R U F$ case,${ }^{54}$ and these cases will be discussed in the following.

\subsubsection{The $A F R C$ case}

The case Prosecutor v. Brima et al., commonly referred to as the AFRC case, was the first international case ever to recognize and develop the crime of forced marriage. Forced marriage was initially not included in the indictment, but after pressure from civil society, ${ }^{55}$ the Prosecutor sought, and was granted leave, to amend the indictment ${ }^{56}$ to include the count of forced marriage as an 'other inhumane act' (new Count 8) cf. Article 2(i) of the Statute. The accused were also charged with other sexual crimes, including rape, sexual slavery and other forms of sexual violence.

\footnotetext{
$46 \quad$ Supra note 14.

47 Agreement Between the United Nations and the Government of Sierra Leone on the Establishment of a Special Court for Sierra Leone.

48 Article 1(1) of the Statute of the Special Court for Sierra Leone.

49 Statute of the Special Court for Sierra Leone.

50 SCSL Rules of Procedure and Evidence.

51 Crimes against humanity, cf. Article 2, war crimes, cf. Article 3, international humanitarian law, cf. Article 4.

52 Cf. Article 5.

53 Prosecutor v. Brima et al.

54 Prosecutor v. Sesay et al.

55 Toy-Cronin (2010) p. 564.

56 Prosecutor v. Brima et al. Decision on Prosecution request for Leave to Amend the Indictment.
} 
With respect to Count 8 , the Trial Chamber found by a majority ${ }^{57}$ that there is "no lacuna in the law which would necessitate a separate crime of 'forced marriage' as an 'other inhumane act". 58 The finding was based on the reasoning that forced marriage is "completely subsumed by the crime of sexual slavery". 59 The Trial Chamber held that Article 2(i) was a residual clause intended to cover "a broad range of underlying acts not explicitly enumerated in Article 2(a) through (h) of the Statute" (the other crimes against humanity), and therefore Article 2(i) must "logically be restrictedly interpreted as applying only to acts of non-sexual nature". ${ }^{60}$ This was contrary to the Prosecutor's submission that forced marriage was "distinct from sexual acts, because they force a person into the appearance of marriage by threat or other coercion", ${ }^{61}$ and that forced marriage as an inhumane act could include sexual violence or slavery but involved other distinct elements as well. ${ }^{62}$ The majority of the Trial Chamber found the evidence presented by the Prosecution insufficient to prove the non-sexual elements of forced marriage. ${ }^{63}$ Furthermore, the Trial Chamber found that the use of the term "wife" amounted to the perpetrator's exercise of ownership over the women, rather than an expression of a conjugal relationship. ${ }^{64}$

In her separate concurring opinion, Judge Sebutinde fully agreed with the Trial Chamber with regard to the classification of forced marriage as a "sexual or gender crime akin to rape, sexual slavery or sexual violence" 65 but went further by differentiating between arranged marriage in peacetime and forced marriage in the context of the conflict. Sebutinde shared the view of expert witness Bangura, that a "clear distinction should be drawn between traditional or religious marital unions involving minors (early or arranged marriages), during times of peace; and the forceful abduction and holding in captivity of women and girls ('bush wives') against their will". ${ }^{66}$ In contrast, Judge Doherty, in her partly dissenting opinion regarding Count 8,

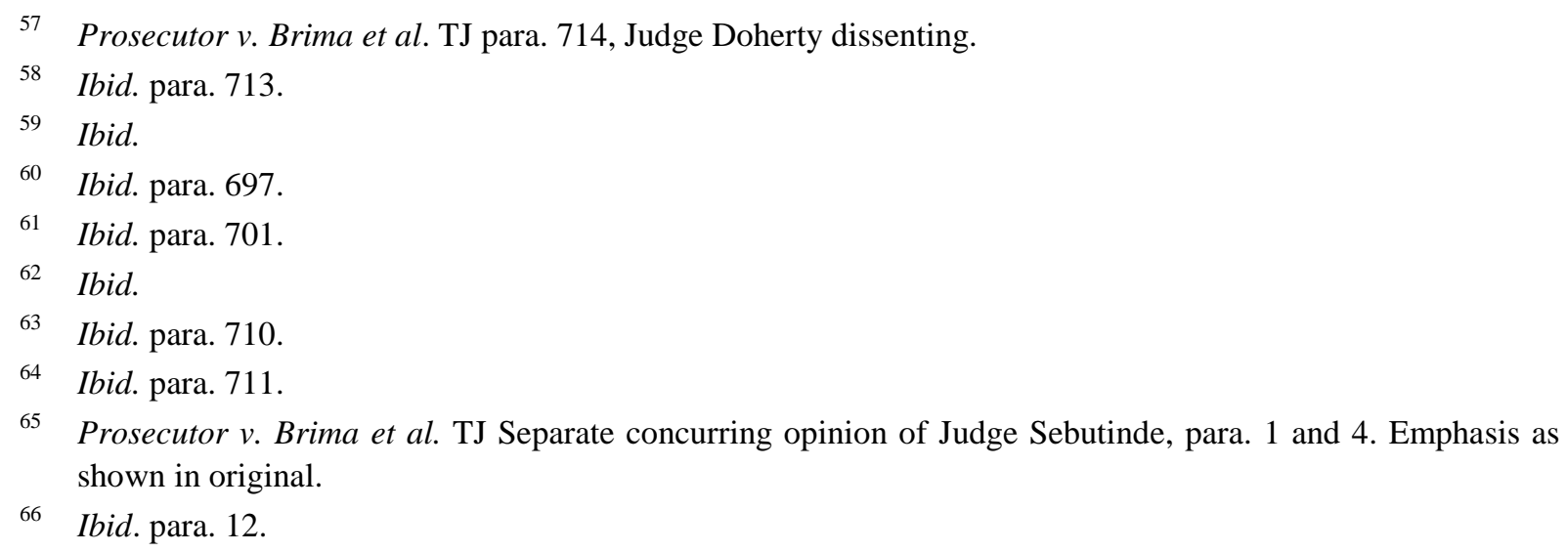


distinguishes the phenomenon of forced marriage from sexual slavery. She regards forced marriage as primarily a non-sexual crime. She focused on the conjugal element of the crime, stating that the central element of forced marriage is "the imposition, by threat or physical force arising from the perpetrator's words or other conduct, of a forced conjugal association by the perpetrators over the victim". ${ }^{67}$

In sum, the majority of the Trial Chamber was not satisfied that the evidentiary submission by the Prosecutor could prove the elements of a non-sexual crime of forced marriage. Even if sufficient evidence would have been brought to prove the non-sexual elements, the Chamber found that "it would not have been of similar gravity to the acts referred to in Article 2(a) to (h) of the Statute". ${ }^{68}$ Count 8 was found to be redundant and was therefore dismissed.

Eight months later, the finding was overturned by the Appeals Chamber. ${ }^{69}$ It held that the Trial Chamber had interpreted the residual provision 'other inhumane act' too restrictively and had therefore "erred in law". ${ }^{70}$ Furthermore, the Appeals Chamber stated that "the Prosecution may have misled the Trial Chamber", ${ }^{, 1}$ by putting Count 8 (forced marriage) together with Counts 6, 7 and $9^{72}$ under the heading 'Sexual Violence'. The Appeals Chamber found that "no tribunal could reasonably have found that forced marriage was subsumed under the crime against humanity of sexual slavery". ${ }^{73}$ Although forced marriage shares some elements with sexual slavery (for example non-consensual sex and the deprivation of liberty), there are distinguishing elements, such as being forced into a conjugal association and the exclusive nature of the relationship, which render it "not predominantly a sexual crime". ${ }^{74}$ This consideration accorded with the dissenting view of Judge Doherty.

The Appeals Chamber held that "forced marriage describes a situation in which the perpetrator through his words or conduct, or those of someone for whose actions he is responsible,

\footnotetext{
67 Prosecutor v. Brima et al. TJ Partly dissenting opinion of Judge Doherty, para. 53.

68 Prosecutor v. Brima et al. TJ para. 710.

69 Prosecutor v. Brima et al. AJ.

$70 \quad$ Ibid. para. 185.

$71 \quad$ Ibid. para. 181.

72 Rape, sexual slavery and outrages upon personal dignity, respectively.

73 Prosecutor v. Brima et al. AJ para. 195.

74 Ibid. para. 195.
} 
compels a person by force, threat of force, or coercion to serve as a conjugal partner resulting in severe suffering, or physical, mental or psychological injury to the victim". ${ }^{75}$ This definition highlights the conjugal act, and forceful context of, forced marriage.

Even though the Appeals Chamber overturned the dismissal of Count 8, and found the accused responsible for forced marriage, they did not enter new convictions. ${ }^{76}$ The reasoning was that the Chamber was "convinced that society's disapproval of the forceful abduction and the use of women and girls as forced conjugal partners (...) is adequately reflected" by finding such criminal conduct as an 'other inhumane act'. ${ }^{77}$

\subsubsection{The RUF case}

The second case was Prosecutor v. Sesay et al. (hereinafter called the RUF case) where the three persons accused were each charged with eight counts of crimes against humanity. ${ }^{78}$ Count 8, concerned forced marriage as 'other inhumane act' under Article 2(i) of the Statute. ${ }^{79}$ The RUF was a rebel group formed in the 1980s with the aim to overthrow the sitting government in Sierra Leone. ${ }^{80}$ The RUF rebels operated similarly to the AFRC rebels; they were known for targeting women and subjecting them to, inter alia, rape, sexual slavery and forced marriage. ${ }^{81}$

Both the Trial Chamber and the Appeals Chamber confirmed and convicted the accused for forced marriage as a crime against humanity under the residual clause 'inhumane acts'. Although the Chambers in the RUF case did not set out its own definition of forced marriage, the Trial Chamber elaborated on the elements of the crime of forced marriage provided for in the $A F R C$ case throughout the judgment. The RUF Appeals Chamber endorsed the definition set out in the AFRC Appeals judgment. ${ }^{82}$ Furthermore, the judges were satisfied with the de-

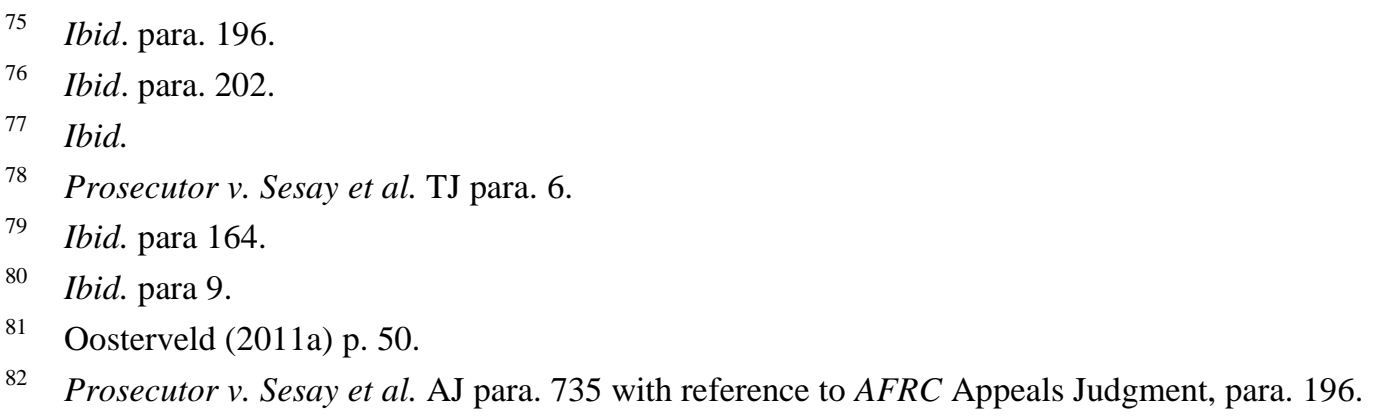


scription of the elements that would constitute the commission of the crime of forced marriage, specified by the Prosecutor, namely that;

\begin{abstract}
"an accused, by force, threat of force, or coercion, or by taking advantage of coercive circumstances, causes one or more persons to serve as a conjugal partner, and the perpetrator's acts are knowingly a part of a widespread or systematic attack against a civilian population and amount to the infliction of great suffering, or serious injury to body or to mental or physical health sufficiently similar in gravity to the enumerated crimes against humanity, then consent is impossible and therefore is not a relevant consideration". 83
\end{abstract}

As seen from the description of the elements constituting the crime of forced marriage, the main contribution of the $R U F$ trial was to evaluate forced marriage in the context of other inhumane acts. When discussing the harm of the imposed conjugal association, the Trial Chamber pointed out that "lasting social stigma (...) hampers their recovery and reintegration into society". ${ }^{84}$ Thus, the Chamber emphasized the broader sociological impact of forced marriage. Another interesting and new contribution was the finding of the Trial Chamber that "the use of term 'wife' by the rebels was deliberate and strategic, with the aim of enslaving and psychologically manipulating the women and with the purpose of treating them like possession". ${ }^{85}$ Thus, the objective of forcing these women into marriage was not only for them to provide sexual and household services, but also as a means of controlling the population through a strategic system. ${ }^{86}$

In sum, the $A F R C$ Appeals judgment was the first ever to consider forced marriage as a separate crime, that of an 'other inhumane act'. The main contribution of the judgment was its definition of the crime, with the emphasis on the conjugal element. The legal significance of the $R U F$ judgments lies in their development of the elements of forced marriage and their connection to the ideology of the RUF rebels. ${ }^{87}$ Also significant is the fact that the judgments in the $R U F$ case did not at any point diverge from the AFRC Appeals Decision.

\footnotetext{
$83 \quad$ Ibid. para. 736.

$84 \quad$ Ibid. para. 1296.

$85 \quad$ Ibid. para. 1466.

86 Oosterveld (2011a) p. 66.

87 Ibid. p. 52.
} 


\subsection{The Extraordinary Chambers for the Courts of Cambodia}

The Khmer Rouge regime was a communist governmental reform which lasted between 1975 and 1979. It is estimated that 1.7 million people died during the period. ${ }^{88}$ Under the regime of the Khmer Rouge, it has been claimed that forced marriage (committed against both men and women) was a widespread practice, allegedly as part of the Khmer's political reform. ${ }^{89}$ The rationale behind the practice of forced marriages was to exert control over the civilian population in matters pertaining to spousal selection, births and sexual relations as a means of ensuring their adherence to the Communist Party of Kampuchea's (CPK). ${ }^{90}$

The Extraordinary Chambers for the Courts of Cambodia (otherwise known as the Khmer Rouge Tribunal, or the ECCC) was created after the Cambodian government reached out to the UN and entered into an agreement to establish the Court. ${ }^{91}$ The Court has personal jurisdiction over those most responsible for national and international crimes, including crimes against humanity, committed during the Khmer Rouge regime in the Democratic Kampuchea (now Cambodia). ${ }^{92}$

Four cases have been brought before the Court. To date, only Case 001 has been concluded, while Cases 002/003/004 are ongoing. ${ }^{93}$ Case 002 was separated into two parts (002/1 and 2) in 2011, in order to make the case more manageable. ${ }^{94}$ Part one of the case was concluded in $2014,{ }^{95}$ with the accused being found guilty of enforced movement of people as a crime against humanity and sentenced to life imprisonment. ${ }^{96}$ Part two of the case includes a charge of forced marriage as a crime against humanity.

88 https://www.eccc.gov.kh/en/about-eccc/introduction (last accessed 7 November 2016).

89 Prosecutor v. Chea et al. Closing Order paras. 845 and 858.

$90 \quad$ Ibid. para. 847.

91 ECCC Agreement.

92 Article 1 of the ECCC law.

93 Case 002 is under proceedings, while Cases 003 and 004 are under investigation.

94 https://www.eccc.gov.kh/en/articles/severance-proceedings-ordered-case-002 (last accessed 7 November 2016)

95 The judgement was appealed. The Appeals judgement is expected to be delivered 23 November this year, https://www.eccc.gov.kh/en/articles/appeal-judgement-case-00201-scheduled-23-november (last accessed 7 November 2016). The author therefore does not address this further, as the appeals judgement will be released after the date of submission.

96 The accused are the same in the two parts of Case 002, however Sary died in 2013 and Thirith died two years later, thus only two defendants on are on trial are Chea and Samphan. 


\subsubsection{Case 002/02}

The accused in the case against Chea, Sary, Samphan, Thirith (Case 002/2) are charged with committing crimes against humanity, genocide and grave breaches of the Geneva Conventions of 1949 as senior leaders during the Khmer Rouge regime. ${ }^{97}$ The Trial Chamber began to hear evidence on the charge of forced marriage on 23 August this year. Forced marriage and rape within the context of forced marriage were charged as 'other inhumane acts' under Article 5 of the ECCC Law. ${ }^{98}$ Forced marriage was originally not included in the indictment but, after the Civil Party Lawyers filed several Supplementary Investigative Requests, ${ }^{99}$ an Order on Request for Investigative Action Concerning Forced Marriage and Forced Sexual Relations was eventually accepted. ${ }^{100}$ Forced marriage and rape within the context of forced marriage were the only sexual and gender-based crimes included in the indictment.

The Closing Order (indictment), submitted by the Co-Investigating Judges ${ }^{101}$ after the investigation, in accordance with Internal Rule 55, undertook a factual and judicial investigation. The Closing Order provides for "a description of the material facts and their legal characterisation by the Co-Investigating Judges, including the relevant criminal provisions and the nature of the criminal responsibility". ${ }^{102}$ Although the Trial Chamber is currently hearing evidence on forced marriage in the ongoing trial, Elander points out that "much work on their representation as crimes is done in the Closing Order" and argues that "the trial and subsequent judgment are to some extent bound by the Closing Order". 103

The factual findings in the Closing Order show that both men and women were forced into marriage under the Khmer regime. ${ }^{104}$ The assignments of spouses were usually made by the

\footnotetext{
97 Prosecutor v. Chea et al. Closing Order paras. 6-9.

98 Ibid. paras. 1430 and 1442.

99 See for example Co-Lawyers for the Civil Parties' Fourth Investigative Request.

100 Accepted 18 December 2009.

101 In contrary to other internationalized tribunals, the investigations at the ECCC are conducted by the two CoInvestigating Judges, based on the investigations by the Prosecutor. The findings made under the investigations are presented in the Closing Order. The following information from the Closing Order is based upon statements from 664 civil parties to the case, cf. the Closing Order para. 861.

102 ECCC Internal Rules 67(2).

103 Elander (2016) p. 170.

104 Prosecutor v. Chea et al. Closing Order para. 842.
} 
Angkar, ${ }^{105}$ on the basis of social class and political standing, although there were local variations to the approach. ${ }^{106}$ The prospective spouses in most cases did not know each other and had no say in the selection. ${ }^{107}$ Mass ceremonies were held where groups of couples, up to a hundred, were wedded at the same time. ${ }^{108}$

Pol Pot, the leader of the Khmer Rouge, stated that these marriages were entered on a voluntary basis; however, the factual findings show that this was not always the case. ${ }^{109}$ Witnesses have testified that their lives were at stake - if they didn't obey they could face violence, death, or being sent to the work camps. ${ }^{110}$ After the marriage had been entered into, the couples were usually ordered to have a short "honeymoon" with the goal to conceive, before separating and returning to their designated workplaces. Some witnesses have testified that they had sex with their spouse due to fear of not complying with the policies under the totalitarian rule. Others have testified to being raped by their husbands, on the Angkar's orders. ${ }^{111}$ The Angkar were reported to be monitoring the consummation, and some spouses were imprisoned for refusing sexual intercourse with their spouse. ${ }^{112}$

The legal findings on forced marriage, made by the Co-Investigating Judges, were split in two sections; "rape in the context of forced marriage" and "other inhumane acts through forced marriage". ${ }^{113}$ The judges found that "the constitutive elements of the crime against humanity of other inhumane acts through acts of forced marriage have been established nationwide". 114

\footnotetext{
105 Means “'Organization' and described the Party as a whole but also the leaders at different levels”, cf. the Closing Order para. 18.

106 Prosecutor v. Chea et al. Closing Order paras. 846-847. Ye (2011) p. 469.

107 Prosecutor v. Chea et al. Closing Order para. 849. However, there were some reports of persons whose wishes were taken into account when choosing a spouse, paras. 851 and 852 .

108 Ibid. para. 844.

109 Ibid. para. 845.

110 Ibid. paras. 849 and 850.

111 Ye (2011) p. 469.

112 Prosecutor v. Chea et al. Closing Order para. 858.

113 Ibid. paras. 1430 and 1442.

114 Ibid. para. 1442.
} 
With respect to the first section, it was found that the legal element of rape, i.e. consummation of marriage, in this context was "one of the crimes used by the CPK leaders to implement the common purpose". ${ }^{115}$

When discussing the actus reus of forced marriage as an inhumane act in the second section, the Judges focused on the fact that the victims were "forced to enter into conjugal relationships in coercive circumstances", causing "serious physical or mental suffering or injury or a serious attack on human dignity of a degree of gravity comparable to that of other crimes against humanity". ${ }^{116}$ The judges did not, however, set out an explicit definition of forced marriage. In the earlier Order on Request for Investigative Action Concerning Forced Marriage and Forced Sexual Relations, the same judges stated that it was not necessary to "conduct a final analysis of the elements of forced marriage" at that stage, finding instead that "due notice of the constitutive aspects of forced marriage can be derived from the AFRC Appeals Judgment of the Special Court of Sierra Leone". ${ }^{117}$ It is notable that this reference to earlier remarks on the elements of forced marriage was not repeated in the Closing Order.

Forced marriage in the context of Cambodia differs in several ways from the abovementioned cases in Sierra Leone, ${ }^{118}$ both men and women were affected and it was the Khmer Rouge regime itself that coerced men and women into, and subsequently enforced, forced marriages. It has therefore been argued that "Cambodia reveals how forced marriage can be expansively interpreted and how the crime can apply in different circumstances". ${ }^{119}$ It is expected that evidentiary hearings on forced marriage will conclude later this year, with a judgment to follow by the end of 2017.

\footnotetext{
115 Ibid. paras. 1430 and 1432. Interestingly, the judges considered the CPK policy to prevent rape, and "despite the fact that this policy did not manage to prevent rape, it cannot be considered that rape was one of the crime used by the CPK leaders to implement the common purpose", but this was not the case in the context for forced marriage, cf. para. 1429.

116 Ibid. para. 1443.

117 Order on Request for Investigative Actions Concerning Forced Marriages and Forced Sexual Relations, paras. 9 and 10.

118 O'Brien (2016) p. 390.

119 Nguyen (2014) p. 18.
} 


\subsection{The International Criminal Court}

The ICC is the first and only permanent international criminal court. The legal basis for the Court's establishment and jurisdiction is the Rome Statute. The ICC investigates and prosecutes individuals for breaches of the most serious crimes of international character; genocide, crimes against humanity and war crimes. ${ }^{120}$ In 2016, two thirds of the states in the world, i.e. 124 , have ratified the Statute and are State Parties. ${ }^{121}$

A total of 23 cases have been brought before the ICC, and three judgments have been rendered; in Katanga and Lubanga, ${ }^{122}$ and Bemba. ${ }^{123}$ Currently, ten situations are subject to investigation by the ICC, where a charge has been issued, or formal investigation has started. One of these situations is Uganda.

\subsubsection{The situation in Uganda and the Ongwen case}

In December 2003, the President of Uganda referred the situation in North Uganda to the ICC, and investigations opened in July 2004. ${ }^{124}$ Five senior leaders of the rebel group Lord's Resistance Army (LRA), including Ongwen, were accused of committing war crimes and crimes against humanity in relation to the armed conflict in North Uganda between 2002 and 2005. The conflict was fought between the LRA and the government of Uganda with the LRA attempting to overthrow the government. ${ }^{125}$ Ongwen's case was separated from the case against the other LRA leaders in $2015 .^{126}$

During the conflict, civilians were systematically targeted by the LRA, causing grave suffering. ${ }^{127}$ An estimated number of 60000 Ugandan children and youth were kidnapped by the rebels, and some of these were forced into marriages with members of the LRA. ${ }^{128}$ The practice of forced marriage in Uganda is strikingly similar to the situation in Sierra Leone, in that

\footnotetext{
120 Rome Statute Article 6, 7 and 8, respectively.

121 South Africa, Burundi and Gambia are in the process of withdrawing, but are as of now still State Parties. https://www.amnesty.org/en/latest/news/2016/10/gambia-withdrawal-from-icc-a-drastic-blow-to-countlessvictims-globally/ (last accessed 7 November 2016).

122 Final judgements have been rendered in Prosecutor v. Katanga and Prosecutor v. Lubanga.

123 Prosecutor v. Bemba, currently on Appeal.

124 Prosecutor v. Ongwen Decision on the confirmation of charges para. 4.

125 Ibid. para. 3.

126 https://www.icc-cpi.int/Pages/item.aspx?name=pr1088 (last accessed 7 November 2016).

127 Prosecutor v. Ongwen Decision on the confirmation of charges para. 3.

128 Carlson and Mazurana (2008) p. 4.
} 
women were abducted from their homes and distributed to individual rebels as wives. Again, these marriages were not formally legal, that is to say they were not recognized by international or Ugandan law. ${ }^{129}$ The married women were subject to multiple crimes; they were, inter alia, sexually abused, forced to cook, clean and carry supplies between camps, in addition to often being impregnated. ${ }^{130}$ Some of the women abductees were also forced to fight. ${ }^{131}$

At the confirmation of charges stage, the Pre-Trial Chamber must assess whether there is sufficient evidence - presented by the Prosecutor - to establish substantial grounds to believe that the accused committed the crimes of which he is charged cf. Article 61(7) of the Rome Statute. The confirmation of charges hearing against Ongwen was concluded on 23 March 2016. All 70 charges, including forced marriage as an 'other inhumane act', were unanimously confirmed. ${ }^{132}$

The main question for the Chamber, with respect to the charge of forced marriage under Article $7(1)(\mathrm{k})$ of the Rome Statute, was whether Ongwen's conduct, his forcing women to serve as conjugal partners, constituted "an other inhumane act of character similar to the acts set out in article 7(1)(a) to (j) intentionally causing great suffering, or serious injury to body or to mental or to physical health". ${ }^{133}$ In the Decision on the Confirmation of Charges, the Pre-Trial Chamber referred to the cases at the SCSL and pointed out that the facts in the cases were similar to, and the legal question the same as in, the Ongwen case. ${ }^{134}$ After referring to the legal requirements of forced marriage set out in the SCSL Appeals Judgments in RUF (para. 736), $A F R C$ (para. 196) and Closing Order in Case 002/2 (para. 1443), ${ }^{135}$ the Pre-Trial Chamber stated that forced marriage "may, in the abstract, qualify as 'other inhumane act' under Article 7 of the Statute". ${ }^{136}$

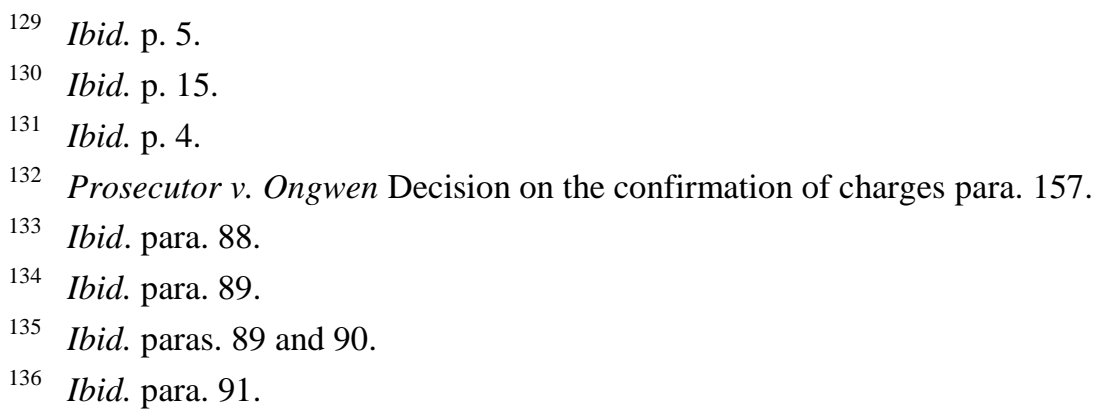


The defence argued that forced marriage was not included within the category of other inhumane acts, because it was already subsumed by the crime sexual slavery. ${ }^{137}$ This argument was dismissed by the judges, who highlighted the differences, in the Ugandan context, between forced marriage and sexual slavery "in terms of conduct, ensuing harm, and protected interests". ${ }^{138}$ The judges acknowledged that some acts are common to both crimes, for example sexual abuse, but noted that "the forced performance of domestic duties" is exclusive to forced marriages. Importantly, the forced performance of domestic duties alone is not sufficient to establish the crime of forced marriage. The central element is the imposition of a "marriage", which the Pre-Trial Chamber defined as "the imposition, regardless of the will of the victim, of duties that are associated with marriage, as well as of the social status of the perpetrator's 'wife"". ${ }^{139}$ Thus, it is the de facto situation, i.e. the "exclusivity of this forced conjugal union" that is determinative, and sets it apart from sexual slavery. ${ }^{140}$ Furthermore, the judges emphasized that victims of forced marriage had their right both to freely enter into marriage and establish a family violated, noting the additional harm that this caused the victims; these were rights, according to the judges, that should be protected. ${ }^{141}$

Judge de Brichambaut issued a separate opinion, criticizing the decision for its shortcomings with regard to both the rationale and evidentiary analysis. ${ }^{142}$ He pointed out that, although the Pre-Trial Chamber's reasoning was limited to "what is necessary", it "must still set out, clearly and precisely, definitions of each of the crimes charged against the accused", and connect it to the evidence. ${ }^{143}$ Interestingly, de Brichambaut listed the crimes he considered to be lacking a definition, ${ }^{144}$ and forced marriage was not amongst them. ${ }^{145}$ The reason for this was not explained; perhaps he was satisfied with the discussion on the elements on forced marriage set out by the Pre-Trial Chamber.

\footnotetext{
137 Prosecutor v. Ongwen Defense brief paras. 128-130.

138 Prosecutor v. Ongwen Decision on the confirmation of charges para. 92.

139 Ibid. paras. 92 and 93.

140 Ibid. para. 93.

141 Ibid. para. 94.

142 Prosecutor v. Ongwen Decision on the confirmation of charges Separate opinion of de Brichambaut para. 2.

143 Ibid. para. 10.

144 Inter alia, murder, torture, other inhumane acts, enslavement as crimes against humanity, cf. para. 18.

145 Prosecutor v. Ongwen Decision on the confirmation of charges Separate opinion of de Brichambaut para. 18.
} 
The Chamber concluded that, based on the evidence presented, forced marriage constituted "the crime of an other inhumane act" and differed from the other crimes charged, including sexual slavery. ${ }^{146}$ The Trial is scheduled to begin 6 December $2016 .{ }^{147}$

\subsection{Is the crime of forced marriage recognized in case law?}

The following Part - 2.5.1 - will compare the definitions and elements of forced marriage set forth in Part 2.2-2.4, which are the only cases where forced marriage has been successfully litigated, or where forced marriage is included in the indictment as a separate crime. Part 2.5.2 discusses whether there is agreement in case law, and includes cases and situations where forced marriages have been prevalent in armed conflicts, but not specifically indicted.

\subsubsection{Definitions and elements of the crime}

It is evident that the elements of forced marriage, as defined in the above discussed cases, vary considerably. The AFRC case highlights the different approaches on defining forced marriage. Although the AFRC Trial Chamber, with the exception of dissenting Judge Doherty, did not set out an explicit definition of forced marriage, it nevertheless discussed the crime. While the Trial Chamber ${ }^{148}$ stated that forced marriage is subsumed under the crime of sexual slavery, and that it is predominantly a sexual crime, the Appeals Chamber ${ }^{149}$ took a different approach of confirming it as an 'other inhumane act'. The Appeals Chamber's definition, and the definition set out by dissenting Judge Doherty, emphasizes the main element to be that of a forced conjugal association. The fact that two Chambers of the same Tribunal and in the same case cannot agree upon the underlying nature of the crime, highlights the difficulties in handling a crime of such complexity.

The Trial and Appeals Chamber in the $R U F$ case relied, ${ }^{150}$ more or less, on the definition put forth by the Appeals Chamber in the AFRC case. ${ }^{151}$ The problem with the $R U F$ Trial judgment is that the discussion of the elements of forced marriage is scattered around the judgment, making it difficult to fully understand how the judges define forced marriage. However,

\footnotetext{
146 Ibid. para. 95.

147 https://www.icc-cpi.int/Pages/item.aspx?name=pr1216 (last accessed 7 November 2016).

148 Prosecutor v. Brima et al. TJ.

149 Prosecutor v. Brima et al. AJ.

150 Prosecutor v. Sesay et al. TJ and AJ.

151 An explicit reference to the definition in the AFRC AJ was made in Prosecutor v. Sesay et al. AJ, para. 735.
} 
the Chambers seem to follow the approach in the AFRC Appeal judgment by relying on the conjugal act, rather than the sexual elements, of the crime. This is supported by the statement that the actus reus of 'forced marriage' is "the imposition of a forced conjugal association". 152 Furthermore, the Trial Chamber portrays the distinguishing element, separating forced marriage from sexual slavery, as "a forced conjugal association based on exclusivity between the perpetrator and the victim". ${ }^{153}$ Sexual slavery lacks this forced conjugal association.

The same approach was taken in the Ongwen case by the ICC Pre-Trial Chamber, ${ }^{154}$ which concluded that the act of "forcing another person to serve as a conjugal partner" constituted an 'other inhumane act'. ${ }^{155}$ Again, the emphasis was laid on the conjugal aspect, rather than the sexual. However, the Ongwen case is only at the confirmation stage, thus, it will be up to the Trial Chamber to decide whether to follow the same line of argumentation as the Pre-Trial Chamber when defining the act of forced marriage.

In contrast, although the Co-Investigative Judges in the Closing Order of ECCC Case 002/2 $2^{156}$ did not define forced marriage, Elander argues that it seems like the judges are not following the approach taken in the AFRC Appeals Judgment. The reason she gives in support of this assertion is that the count of rape in the context of forced marriage and the count of forced marriage per se "focus on the 'consummation of marriage' - in other words: sex. Or, rather, rape." 157 The author would argue otherwise: It seems that the judges are following the SCSL practice of relying on conjugal relationships as the main element, by categorizing it as an 'inhumane act'. The Closing Order puts the main focus on the practices common to forced marriages -the ceremonies and coercive circumstances - highlighting how they diverged from traditional marriage practices in Cambodia. The sexual elements of the act received less attention under the discussion of forced marriage as a separate crime.

In sum, it appears that a shift has taken place - from defining forced marriage as a predominantly sexual crime (sexual slavery), to focusing on the conjugal relationship and therefore

\footnotetext{
152 Prosecutor v. Sesay et al. TJ para. 1295.

153 Prosecutor v. Sesay et al. TJ para. 2307.

154 Prosecutor v. Ongwen Decision on the confirmation of charges.

155 Ibid. paras. 91 and 95.

156 Prosecutor v. Chea et al. Closing Order.

157 Elander (2016) p. 173.
} 
categorizing the crime as an 'other inhumane act'. Three elements of forced marriage can be drawn from the jurisprudence, based on the definition in the AFRC Appeals judgment: (i) force, threat of force or coercion; (ii) a conjugal association; and (iii) severe suffering, or mental or psychological injury to the victim. ${ }^{158}$

Although progress has been made to clarify the elements of the crime of forced marriage, there are still many fundamental issues that need clarification. For example, the definition in the AFRC Appeals judgment has been criticized for being "vague", 159 "fraught with ambiguity" 160 and "failing to adequately address the non-sexual elements of forced marriage". 161 Oosterveld has, moreover, questioned whether "a definition of 'forced conjugal association' actually enhances international criminal law's understanding of the crime". ${ }^{162}$

Eboe-Osuji goes even further and suggests that the Prosecutor and Appeals Chamber in the $A F R C$ case made up the crime of forced marriage, especially with regard to "the very definition of forced marriage", ${ }^{163}$ without using a single legal authority or "source outside of their own authority". ${ }^{164}$ Furthermore, and common to all the cases, is that they lack pervasive arguments as to whether forced marriage is a separate crime, and what its elements are. These critics, with which the author agrees, can result in lack of certainty surrounding the crime of forced marriage.

\subsubsection{A recognized crime?}

A group of legal scholars have asserted that, with the charges confirmed by the Pre-Trial Chamber in the Ongwen case, ${ }^{165}$ "there is consensus in international criminal law on the charging and conviction of forced marriage as a crime against humanity of other inhumane acts" ${ }^{166}$ The following draws on examples from cases where elements of forced marriage have been prevalent in a conflict, but have not been indicted as a separate crime, and discuss

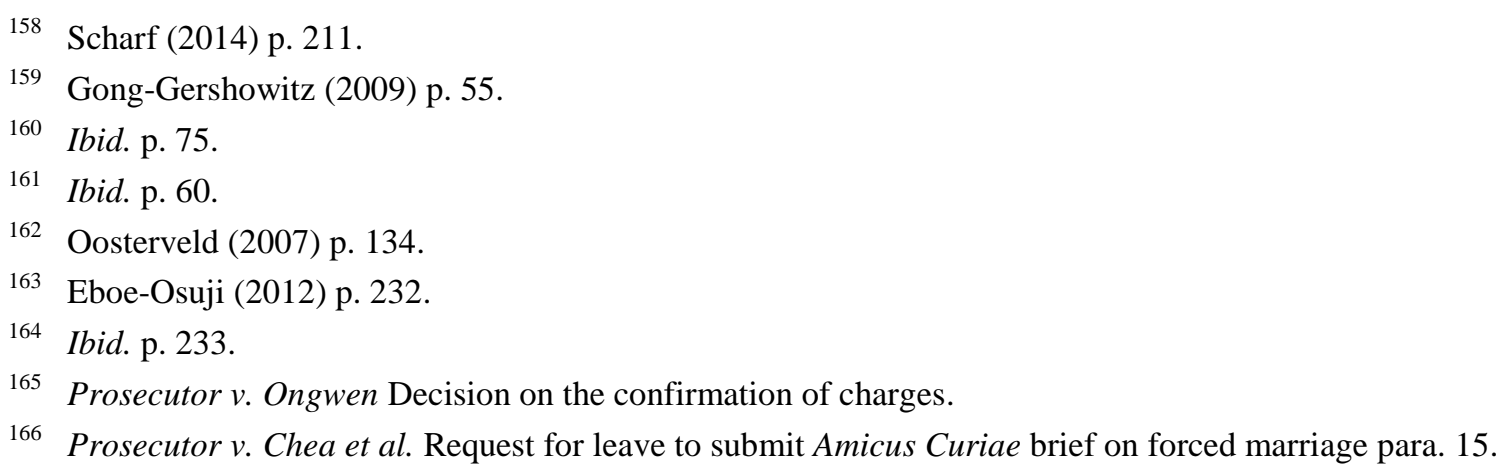


whether the statement on consensus really tallies with the reality. This Part will address the question whether ICL has reached a point of recognition of forced marriage as a separate crime. $^{167}$

The first judgment on forced marriage as a separate crime against humanity in the $A F R C^{168}$ case was widely hailed by civil society for breaking new ground. ${ }^{169}$ After $A F R C$, much hope was subsequently placed on the SCSL to further develop the definition and elements of this "new" crime against humanity in its future cases. The focus that the ARFC Appeals judgment had on the conjugal relationship rather than the element of ownership that is part of sexual enslavement was upheld in the RUF case. ${ }^{170}$ Thus, the emphasis on the conjugal element and categorization of forced marriage as an 'other inhumane act' would therefore seem to be the path taken by the SCSL. ${ }^{171}$

Nevertheless, to further complicate the picture, in the last case of the SCSL against the former President of Liberia - Charles Taylor - forced marriage was not explicitly charged by the Prosecutor. ${ }^{172}$ Rape and sexual slavery as crimes against humanity were the only sexual and gender-based charges brought against him, this despite "extensive testimony (...) regarding forced conjugal association" submitted by the witnesses. ${ }^{173}$ Instead, evidence concerning forced marriage was heard during trial proceedings - in the context of sexual violence. ${ }^{174}$ The Trial Chamber in Taylor implicitly supported the findings of the Trial Chamber in AFRC by highlighting that forced marriage involved sexual slavery, in addition to forced labour. ${ }^{175}$ The judges opposed using the term "forced marriage" because (i) it was not "helpful in describing what happened to the victims"176 and (ii) it was not commensurate with marriage "in the uni-

\footnotetext{
167 Eboe-Osuji (2012) p. 222.

168 Prosecutor v. Brima et al.

169 Gong-Gershowitz (2009) p. 53.

170 Prosecutor $v$. Sesay et al.

171 It should be noted that in the third trial at the SCSL, the Prosecutor v. Norman et al. (CDF case), the Prosecution wanted to include forced marriage as an 'other inhumane act' in the indictment, but the request was dismissed by the Trial Chamber (Thompson (2014) p. 226).

172 Prosecutor v. Taylor. TJ para. 422.

173 Ibid.

174 Ibid.

175 Ibid. para. 425.

176 Ibid. para. 426.
} 
versally understood sense of consensual and sacrosanct union". ${ }^{177}$ Instead, they proposed it should be considered "a conjugal form of enslavement". ${ }^{178}$ The Trial Chamber put emphasis on the victim's deprivation of liberty and the ownership exercised by the perpetrator over the victim, in addition to acknowledging the sexual and non-sexual acts that occurred during the enslavement. $^{179}$

The fact that the Chamber in Taylor did not follow the reasoning in the AFRC Appeals judgment does not mean that the Chamber in Taylor reverted to the position taken by the Trial Chamber in $A F R C$ i.e. that forced marriage is a predominantly sexual crime, completely subsumed by sexual slavery. It seems as if the judges rather proposed a third way of defining the act of forced marriage - namely as conjugal enslavement, falling "within the definition of enslavement". ${ }^{180}$ The Chamber further noted that conjugal slavery is a "distinctive form of sexual slavery" because the associated non-sexual acts of the crime, such as forced labour, are simply descriptive and not "a definitional element of a new crime". ${ }^{181}$ The conclusion was that these non-sexual elements are not new, and therefore, forced marriage/conjugal enslavement is not a new crime. ${ }^{182}$

The SCSL judgments have indeed provided for many legal advances in ICL with respect to the crime of forced marriage. At the same time, the different definitions and categorizations either as sexual slavery, conjugal slavery or as an 'other inhumane act' - provide cause for confusion.

It must be noted that, before the time of the SCSL, the ad hoc tribunals had in some cases touched upon the practice of forced marriage in the Former Yugoslavia and Rwanda (although the charge of forced marriage was never put forth in any of the indictments). In the case Kvočka et al., the ICTY Trial Chamber stated that sexual violence could "also include such crimes as sexual mutilation, forced marriage, and forced abortion (...)". ${ }^{183}$ The reasoning that

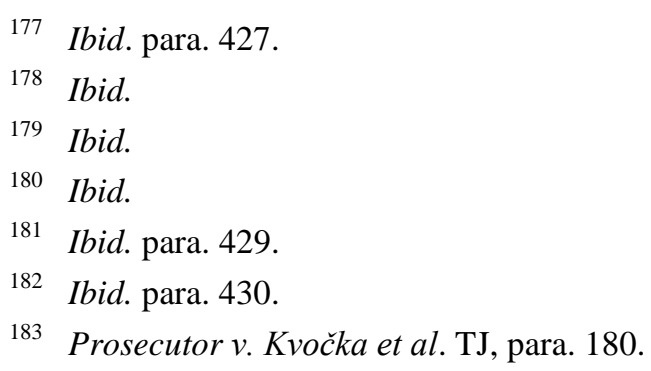


forced marriage could constitute a sexual crime was, perhaps, built on the findings in the Akayesu case by the ICTR. ${ }^{184}$ In Akayesu, witness NN testified that the perpetrator "had locked her in his house, took her out of the group and said that she was his wife". ${ }^{185}$ The practice of forced marriage was thus prevalent in Rwanda, ${ }^{186}$ but rarely spoken about; ${ }^{187}$ however, sexual violence was defined in a very broad way, with the intention of encapsulating many acts, including forced marriage. ${ }^{188}$ Kalra, a legal scholar, has argued that the ICTR should have used "similarly broad parameters when addressing forced marriage". ${ }^{189}$ Although the Prosecutor's Office was aware that forced marriages took place on a wide scale during the genocide, the crime was never included in the indictment. ${ }^{190}$ In Kunarac, the ICTY Trial Chamber dealt with a situation with facts quite similar to the "bush wives" in Sierra Leone. ${ }^{191}$ Two girls had been taken captive and repeatedly raped in exclusive relationships with their capturers. ${ }^{192}$ Furthermore, they had been forced to "obey all demands" of the perpetrator, in addition to having to "do household chores". ${ }^{193}$ The Trial Chamber placed emphasis on the duration of captivity and the ownership relationship, finding Kunarac guilty of rape and enslavement as crimes against humanity. ${ }^{194}$ Common to these cases at the ad hoc tribunals is that forced marriage was not assessed as a separate crime.

Before the ongoing Ongwen case, ${ }^{195}$ the ICC had the opportunity to address forced marriage in the Katanga case. ${ }^{196}$ Katanga, together with Chui, was a leader of a rebel group in the Democratic Republic of the Congo. Katanga was accused of war crimes and crimes against humanity, including a count of sexual slavery. The Prosecution was aware that "young girls were abducted and forced to become wives of combatants", ${ }^{197}$ however, forced marriage was

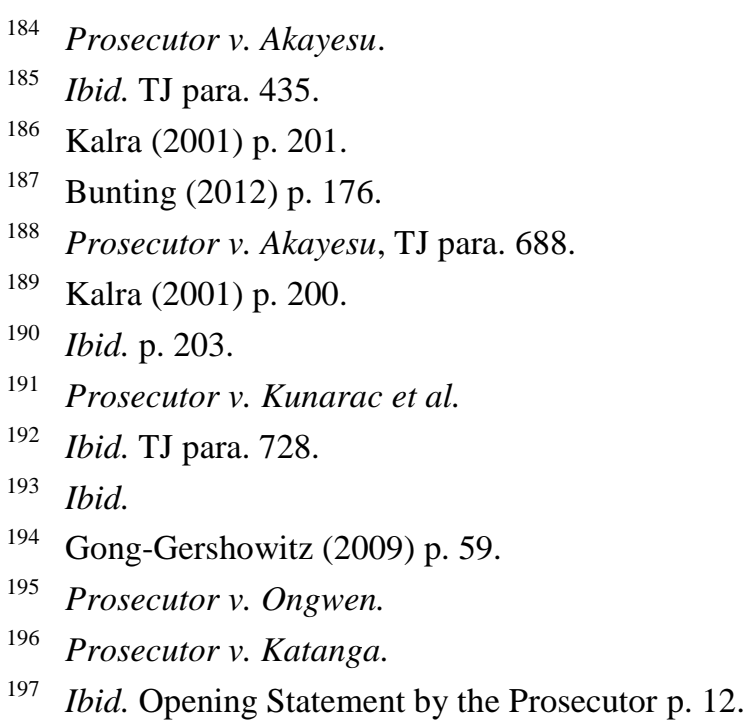


not included as a separate crime under 'other inhumane acts' in the indictment. The Pre-Trial Chamber made clear its view that "sexual slavery also encompasses situations where women and girls are forced into 'marriage', domestic servitude or other forced labour involving compulsory sexual activity (...)" ${ }^{198}$ Interestingly, the decision on the confirmation of charges in Katanga was delivered in September 2008, approximately six months after the final judgment in the AFRC case was delivered. It is remarkable that the judges in Katanga did not take this latest judicial development into consideration. Although the Trial Chamber in Katanga could have adjourned the hearing and requested the Prosecutor to consider amending the charges, in accordance with Article 61(7)(c) of the Rome Statute, it did not take such action. Gekker suggests that this can be explained by the lack of international jurisprudence on forced marriage. $^{199}$

From the discussion in this Part, it is clear that there exists an unsettling gap in international jurisprudence with respect to defining and categorizing the crime of forced marriage. Why is the practice so diverse? The answer might lie in the difficulty in defining international crimes, and even more so, forced marriage. Needless to say, forced marriage is a complicated and multi-layered crime for which it is difficult to provide a definition. Another reason might be that it is felt there is no need for a new and separate crime since forced marriage can be subsumed under 'other inhumane acts'. As (will be) explained in Part. 3.2.2, an act can constitute an inhumane act if it meets the general criteria, i.e. a certain threshold. At the same time, in the opinion of the author, it is necessary to know the elements of the crime - at least to some extent - in order to make this assessment. Without knowing which acts constitute forced marriage, how can one say that these constituent acts are of similar character and gravity as the other, already enumerated, crimes against humanity? Furthermore, in order to demarcate and distinguish forced marriage from other, non-criminal acts (for example arranged marriage), a clarification in needed.

Another consideration is that the definition of a crime does not have to be identical for every international tribunal in order for forced marriage to be recognized as a crime. The different tribunals enjoy autonomy to decide which definitions are most suitable to cover the specific criminal acts that fall within their jurisdiction if the crime itself is neither codified in its Sta-

\footnotetext{
198 Ibid. Decision on the confirmation of charges para. 431.
}

199 Gekker (2014) p. 106 and 107. 
tute nor has customary international law status (lacking state practice or opinio juris). ${ }^{200}$ At the same time, it is common for international criminal tribunals to rely on each other's clarifications in case law when determining the law, by cross-referencing. ${ }^{201}$ That being said, the tribunals are not bound by each other's jurisprudence. There are countless examples where, for example, the ICTY has deviated from the ICTR or vice-versa, not to mention from the jurisprudence by ECCC or SCSL. Even the ICC is not legally bound by its previous decisions - it may, however, use the principles and rules of law developed in previous cases, if it so wishes. $^{202}$ The lack of binding jurisprudence in ICL may, at the same time, lead to fragmentation. Fragmentation, as seen with forced marriage, "raises challenges not only for coherence, but also for determining the precise customary law position on controversial questions". ${ }^{203}$

In sum, the most recent cases adjudicated before the international tribunals show an increasing and evolving trend of criminalizing forced marriage. ${ }^{204}$ Despite this trend, it is evident that different approaches have been developed in case law; forced marriage has been charged and convicted as an 'other inhumane act' and it has been deemed a sexual crime subsumed under 'sexual enslavement'. In other cases (although forced marriage was not specifically indicted), forced marriage have been regarded as a "conjugal enslavement" or just enslavement. ${ }^{205}$ Thus, practice has to this date been incoherent. It is clear that there is room for harmonization, and hopefully the ICC will help in that regard in the Ongwen case. ${ }^{206}$

In conclusion, the statement presented in the beginning of this Part alleging a "consensus in international criminal law on the charging and conviction of forced marriage as a crime against humanity of other inhumane acts" does not reflect reality. ${ }^{207}$ There is a growing trend in indicting forced marriage as an 'other inhumane act'; however, this practice is not uniform. Furthermore, forced marriage has been recognized as a crime; however, a clearer definition is needed. ${ }^{208}$

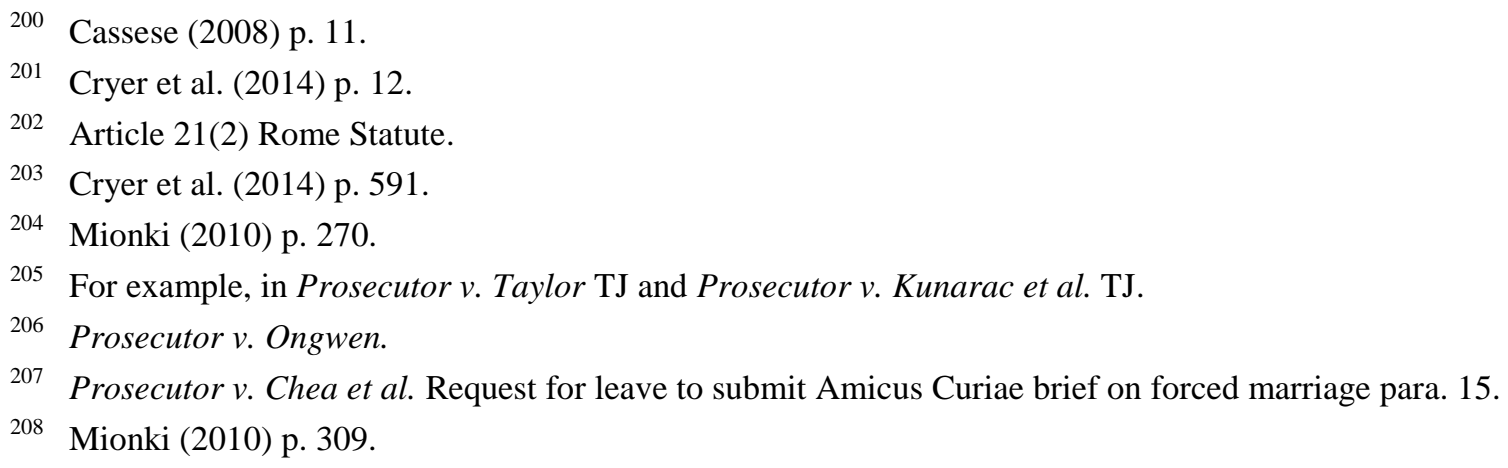




\section{Forced marriage as a separate crime against humanity}

\subsection{What is a crime in international criminal law?}

In Part 2 the focus was on the recognition of forced marriage in case law, with emphasis on its definition and elements. The following will deal with forced marriage as a separate crime against humanity in a broader context, whereby the chapeau elements of a crime against humanity will be connected to the new crime of forced marriage. Possible legal categorizations of forced marriage will also be discussed. To begin with, the framework for what constitutes a crime in ICL shall be clarified.

International crimes "are breaches of international rules entailing the personal criminal liability of the individuals concerned". ${ }^{209}$ More specifically, international crimes includes "all norms that establish, exclude, or otherwise regulate" individual criminal responsibility. ${ }^{210}$ These norms result from international customary rules or statutory provisions if they have been codified. ${ }^{211}$ International customary accepted "core crimes" that give rise to criminal responsibility are, inter alia, crimes against humanity. ${ }^{212}$ This does not, however, mean that all separate crimes against humanity automatically have international customary status. In fact, Eboe-Osuji stated four years ago that "there is no evidence that forced marriage has been recognized under customary international law as a crime". ${ }^{213}$ The issue of the international customary status of forced marriage has not been before any of the tribunals, so its status has not been given an authoritative clarification. In any case, forced marriage might acquire customary status in the future, if States and tribunals begin to discuss and recognize forced marriage as a separate crime.

\subsection{The chapeau elements}

The core (crime) category of crimes against humanity has evolved from humanitarian principles governing armed conflicts and is largely a codification of customary international law. ${ }^{214}$ In order for forced marriage to be criminalized and give rise to individual criminal responsi-

\footnotetext{
209 Cassese (2008) p. 11.

210 Werle and Jessberger (2014) p. 31.

211 Cassese (2008) p. 11.

212 Cryer et al. (2014) p. 4.

213 Eboe-Osuji (2012) p. 228.

214 deGuzman (2011) p. 62 and 65.
} 
bility, the contextual - also called chapeau - elements of crimes against humanity must be fulfilled. The following will use the Rome Statute as a starting point, because the chapeau elements largely reflect "the agreement of the majority of the world's states concerning the definition of crimes against humanity". ${ }^{215}$

According to Article 7 of the Rome Statute, a crime against humanity "means any of the following acts when committed as part of a widespread or systematic attack directed against any civilian population, with knowledge of the attack". It has been argued that the elements constituting a crime against humanity "provide the moral basis for labelling particular inhumane acts crimes against humanity and justify the exercise of international jurisdiction." ${ }^{216}$ Article 7 thus sets out three chapeau elements, which must be fulfilled for a crime of forced marriage to be prosecuted as a crime against humanity. Firstly, the crime of forced marriage must be part of a widespread or systematic attack. This requirement is related to the justification that only the most serious crimes, committed on a certain scale, are of international concern. ${ }^{217}$ Secondly, the imposition of marriage must be directed against a civilian population. Thus, civilians must be the primary target. Thirdly, the perpetrator must have knowledge of the attack. Knowledge of the attack, meaning the "broader context in which his actions occur", i.e. the attack directed against a civilian population, is necessary in order to make one culpable. ${ }^{218}$ If these requirements are fulfilled, forced marriage can be prosecuted as a crime against humanity.

\subsection{The legal categorization of forced marriage}

\subsubsection{Other inhumane acts}

The residual clause 'other inhumane act' is to be found in the Statutes of the ICTR, ICTY, SCSL, ICC and ECCC. ${ }^{219}$ The purpose of the clause is to serve as a catch-all provision. ${ }^{220}$ The wording in Article 7(1)(k) of the Rome Statute, that "other inhumane acts of a similar character intentionally causing great suffering, or serious injury to body or to mental health or phys-

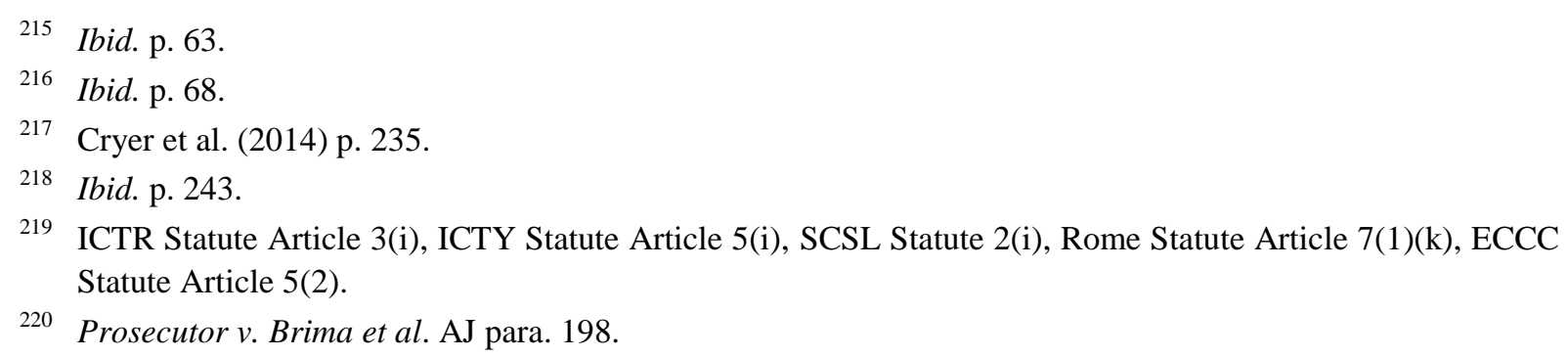


ical health", is broad, intended to cover crimes that the drafters did not think of. The elements are further clarified in ICC Elements of Crimes, adding a requirement that the "perpetrator was aware of the factual circumstances that established the character of the act". Moreover, "“character' refers to the nature and gravity of the act". 221

Inhumane acts recognized previously in case law have, inter alia, included "severe bodily harm, beatings and other acts of violence, (...) inhumane and degrading treatment, forced prostitution, forced disappearance, sniping at civilians". ${ }^{222}$ These acts have been deemed to be of similar nature and gravity, reaching the same suffering-threshold, as the other, already explicit crimes against humanity. The Pre-Trial Chamber in Ongwen pointed out that these assessments are largely factual, with the exception of the test whether the gravity threshold has been met - which is a legal question. ${ }^{223}$ Importantly, the assessment must be done on a caseby-case basis. $^{224}$

Up to the present day, discussions in case law have mainly centred around the question whether to put forced marriage in the category of sexual slavery or in that of 'other inhumane acts'; however, forced marriage has only been successfully prosecuted as an 'other inhumane act'. The judges in AFRC Appeals, ${ }^{225} R U F,{ }^{226}$ Ongwen $^{227}$ and $002 / 2^{228}$ all found the requirements for inhumane acts to be fulfilled when discussing forced marriage. Despite this, some legal scholars have contested the viewpoint that forced marriage should be regarded as an 'other inhumane act'. For example, Nguyen argues that prosecuting forced marriage as an inhumane act "diminished the severity of the crime, especially in contrast with the other crimes" previously recognized as such acts. ${ }^{229}$ Similar arguments have been put forth by Palmer, highlighting that full recognition of forced marriage will "prevent future tragedies, properly recognize the suffering of the victims, and facilitate an examination of the tradition

\footnotetext{
ICC Elements of Crimes Article 7(1)(k) footnote 30.

222 Schabas (2010) p. 185.

223 Prosecutor v. Ongwen Decision on the confirmation of charges para. 88 .

224 Prosecutor v. Brima et al. AJ para. 184.

225 Ibid.

226 Prosecutor v. Sesay et al.

227 Prosecutorv. Ongwen.

228 Prosecutor v. Chea et al.

229 Nguyen (2014) p. 25.
} 
marital union within different cultures across the world." ${ }^{230}$ Thus, many have voiced concerns about placing forced marriage in the residual clause, simply because it is not adequate enough and it does not reflect the multi-layered character of the crime.

\subsubsection{Sexual slavery}

In order for forced marriage to gain a proper definition, one must separate it from other, already defined, crimes against humanity. ${ }^{231}$ Gong-Gershowitz pointed out that one of the main flaws in the $A F R C$ judgments ${ }^{232}$ was the "muddy distinctions between (...) forced marriage and sexual slavery". ${ }^{233}$ It is clear that problems arise with regard to forced marriage because the crime may often intersect with other international crimes, ${ }^{234}$ such as torture, forced labour, enslavement, in addition to sexual crimes such as rape, sexual slavery, forced pregnancy, or other sexual violence. The following will illustrate difficulties in separating forced marriage from sexual slavery.

As seen in the jurisprudence discussed in Part 2, there has been a divide amongst the Judges in how to define and categorize forced marriage. One of the main questions before the $A R F C$ Appeals Chamber ${ }^{235}$ was whether forced marriage is a predominantly sexual crime - a lex specialis of the crime sexual slavery, e.g. conjugal enslavement, or if it should be recognized as a new crime against humanity falling within the category an 'other inhumane act'.

Sexual slavery was codified as a crime against humanity for the first time in the Rome Statute, ${ }^{236}$ together with other acts of sexual violence. This codification built upon the jurisprudence in the Kunarac case at the ICTY from 2001, where the elements were defined for the first time. ${ }^{237}$ The elements of the crime of sexual slavery, listed and codified in the ICC Elements of Crimes, necessities: (i) that the perpetrator exercised ownership over a person and thereby depriving the person of liberty, (ii) that the perpetrator caused the person to engage in

\footnotetext{
230 Palmer (2009) p. 159.

231 Nguyen (2014) p. 18.

232 Prosecutor v. Brima et al.

233 Gong-Gershowitz (2009) p. 60.

234 Oosterveld (2011a) p. 72.

235 Prosecutor $v$. Brima et al.

236 Frulli (2008) p. 1036.

237 Prosecutor v. Kunarac et al. TJ.
} 
acts of sexual nature, and iii) that the chapeau elements have been fulfilled. ${ }^{238}$ The most authoritative elements of forced marriage were put forth by in by the judges in the AFRC Appeals case ${ }^{239}$ and subsequently built upon in recent jurisprudence, ${ }^{240}$ requiring: (i) compelled by force, threat of force or coercion, (ii) a conjugal association, and (iii) severe suffering, or physical, mental or psychological injury to the victim. Indeed, and as seen from the above constituent elements, sexual slavery and forced marriage share many similarities. ${ }^{241}$ The following will analyse and highlight the distinction between these crimes, based on the above listed elements for forced marriage.

\section{(i) Compelled by force, threat of force or coercion}

The perpetrator in both crimes sexual slavery and forced marriage uses coercion/threats in order to obtain control over the victim. The Appeals Chamber in RUF elaborated on this, stating that "the absent of consent is neither an element of sexual slavery nor of forced marriage" 242 - "genuine consent was not possible"243 because of the hostile and coercive circumstances the victims were trapped in. It is difficult to separate the crime of sexual slavery from the crime of forced marriage based on this requirement.

\section{(ii) A conjugal association}

The exercise of ownership over the victim is a common element in both crimes; however, for sexual enslavement the relationship is one of ownership and enslavement, rather than of conjugal association (wife/husband). The central element in the crime of forced marriage, which has been pointed out in AFRC Appeals, RUF, Ongwen and 002/2 is the "imposition of "marriage' on the victim", that is to say a conjugal association. ${ }^{244}$

Moreover, the Pre-Trial Chamber in Ongwen held that forced marriage differs from sexual slavery "in terms of conduct, ensuing harm, and protected interests". ${ }^{245}$ What is meant by

238 ICC Elements of Crimes Article 7(1)(g)-2.

239 Prosecutor v. Brima et al. AJ. para. 196.

240 Prosecutor v. Sesay et al. AJ paras. 735-6, Prosecutor v. Chea et al. Closing Order para. 1443, Prosecutor v. Ongwen Decision on the confirmation of charges paras. 89-90.

241 Mibenge (2013) p. 109.

242 Prosecutor v. Sesay et al. AJ para. 734.

243 Ibid. TJ para. 1466.

244 Prosecutor v. Ongwen Decision on the confirmation of charges para. 93.

245 Ibid. para. 92. 
"conduct" is not explicitly elaborated upon but it might refer to other acts associated with the marriage, such as rape, forced pregnancy, child rearing etc. Rape and other sexual violence might (and most often does) occur in forced marriage; however, the most recent jurisprudence has held that elements of sexual violence are not required because forced marriage is not predominantly a sexual crime. In contrast, the sexual component is necessarily a component in sexual slavery. The Pre-Trial Chamber further highlights "the performance of domestic duties" as an element which indicates forced marriage. ${ }^{246}$ However, as seen in Kunarac, the women who served as sexual slaves were also obliged to do "household chores". ${ }^{247}$ Therefore, one could argue that these duties are not exclusive to the crime of forced marriage.

The most prominent distinction between the crime of forced marriage and that of sexual slavery is that forced marriage requires a conjugal association. ${ }^{248}$ A conjugal association necessitates an exclusive relationship between the perpetrator and victim, ${ }^{249}$ which has been evident in the cases discussed above. Of these, it was only in the case law of Cambodia that forced marriages were legally valid marriages. Whether or not forced marriages were legal was found "irrelevant" in Ongwen. ${ }^{250}$ It was enough to prove that these marriages were de facto entered into. Moreover, emphasis has been placed by the judges in Ongwen on the violation of the institution of marriage. ${ }^{251}$ The right to freely enter into a marriage and form a unit of family is protected in most societies, a right which is infringed in the event of forced marriages. To compare, the element of conjugal association is absent in situations of sexual slavery.

\section{(iii) Severe suffering, or mental or psychological injury to the victim}

It cannot be disputed that victims of both sexual slavery and forced marriage suffer greatly. However, as held in Ongwen, the victims of forced marriage suffered a "separate and additional harm to those of the crime of sexual slavery". 252 The label "wife" has been deemed to cause a different kind of injury, due to the obligations associated with the conjugal union in addition to the intimate long-lasting relationship. As described by Scharf, the victims of

\footnotetext{
246 Ibid.

247 Prosecutor v. Kunarac et al., TJ para. 728.

248 Jain (2008) p. 1030.

249 Prosecutor v. Brima et al. AJ para. 195.

250 Prosecutor v. Ongwen Decision on the confirmation of charges para. 93.

251 Ibid. para. 94.

252 Ibid. para. 94.
} 
forced marriage (in Sierra Leone) were 'indefinably and inexorably bound, 'married', to the men who victimize them". ${ }^{253}$ Furthermore, the stigmatization these wives face cannot be understated. For example, many of the rebel wives in Sierra Leone and Uganda were not welcomed when returning to their home communities after the conflict was over. ${ }^{254}$ The women were deemed to be rebels, tainted or damaged goods, and therefore unable to reintegrate back in their communities. ${ }^{255}$

To conclude, in recent case law, several factors have been crystalized as distinguishing forced marriage from sexual slavery. It is evident that "sexual slavery fails to encompass the full reality of the crime of forced marriage". ${ }^{256}$ Although the separation of the two crimes has been the subject of a great debate in legal writings, the debate might soon be outdated, if the Trial Chambers at ECCC and ICC follow the path laid down by the Co-Investigative judges and Pre-Trial Chamber. ${ }^{257}$

\subsubsection{Other legal categorizations?}

As seen in Part 3.3.1, some legal scholars have advocated for the full recognition of forced marriage as a separate crime, thus removing it from the 'other inhumane acts' box. Moreover, it seems as though a shift has taken place, from recognizing forced marriage as sexual slavery to focusing on the conjugal element (Part 3.3.2).

One possible legal categorization of forced marriage is that of enslavement, which is listed in Article 7(1)(c) of the Rome Statute. By prosecuting forced marriage as enslavement, and not sexual slavery, one recognizes the non-sexual components of the crime. This seems to be in line with the arguments in the Taylor case, which promoted conjugal enslavement as falling "within the definition of enslavement". ${ }^{258}$ This legal categorization has not gained much support in legal theory, however. ${ }^{259}$ Further, the approach has not been followed in the latter case law.

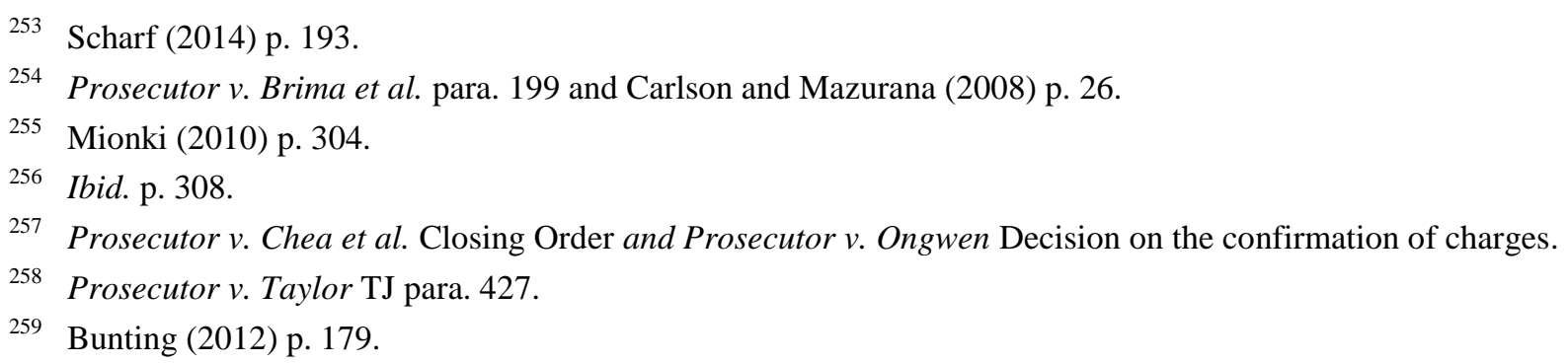


In theory, forced marriage could be incorporated into the Rome Statute as a separate crime against humanity. This would require an amendment of Article 7 of the Statute by the Assembly of States Parties cf. Article 121 in the Rome Statute. A proposed amendment by a Member State requires a vote of two thirds in favour of the amendment, if consensus is not achieved.

However, in practice, the author would assess that the likelihood of the State Parties reaching an agreement based on negotiations to amending the Statute is very low. Tensions between State Parties have risen in the last years, partly due to a number of African countries withdrawing, or planning to withdraw, from the Court. ${ }^{260}$ Furthermore, reaching an agreement on the elements of the crime, for inclusion in the ICC Elements of Crimes, would be difficult due to the nature of forced marriage. Also relevant is that forced marriage is similar to the arranged marriages that take place in times of peace, with the latter practice having long traditions in many non-European states. ${ }^{261}$ Explicitly criminalizing an act - forced marriage - that is so similar to an accepted practice is highly unlikely.

\section{Contrary to the principle of legality?}

\subsection{Introductory remarks}

The principle of legality - nullum crimen sine lege - is a fundamental principle in international prosecution and thus applies across the international tribunals. ${ }^{262}$ Moreover, the principle can be found in UDHR Article 11(2) and the Rome Statute Article 22(1). The equitable consideration behind this principle is to create legal certainty, meaning that an individual can know whether his planned action is within the boundaries of the law or not. ${ }^{263}$ This protects the fundamental rights of an accused. ${ }^{264}$ Thus, the act must have been criminalized under the applicable law, as a codified provision unless it is part of customary international law. In prosecuting new crimes against humanity, practice demands that the principle of nullum

\footnotetext{
260 Supra note 119.

261 https://www.hrw.org/world-report/2016/ending-child-marriage (last accessed 14 November 2016).

262 Lincoln (2010) p. 137.

263 Cryer et al. (2014) p. 18.

264 Scharf (2014) p. 197.
} 
crimen sine lege is observed. ${ }^{265}$ Since forced marriage has, until now, only been successfully adjudicated as an 'other inhumane act', the following will maintain this focus when discussing its legality.

Domestic civil law traditions tend to favour the doctrine of strict legality, in contrast to substantive justice. ${ }^{266}$ The latter does not require the act to be criminalized at the time of conduct, because the public interest prevails. Cassese argues that ICL is moving toward the strict doctrine, and highlights four of its elements: ${ }^{267}$ (i) the "criminal offences may only be provided for in written law", (ii) "criminal legislation must abide by the principle of specificity", (iii) the "criminal rules may not be retroactive", and (iv) "resort to analogy" is prohibited. ${ }^{268}$

\subsection{Written law}

Although the prohibition of forced marriage is manifested in human rights instruments, ${ }^{269}$ it has not been explicitly criminalized in any of the international criminal tribunals' Statutes. Nor can forced marriage be regarded as customary international law, as discussed in Part 3.1. The residual clause 'other inhumane act' has been inserted into the Statutes of the different tribunals to cover acts not explicitly provided for in the Statute. ${ }^{270}$ Thus, it was the intention of the drafters to allow the international criminal tribunals to prosecute new behaviours that reach the requirements of an 'other inhumane act'. Therefore, if forced marriage satisfies the elements of an inhumane act, it will satisfy the requirement of written law.

\subsection{Specificity}

Specificity requires that the criminal conduct is specific and clear. ${ }^{271}$ Thus, the definition of a crime must be specific enough for a potential perpetrator to know whether or not the act is criminalized. $^{272}$

\footnotetext{
265 Ibid.

266 Cassese (2008) p. 36.

267 Ibid. p. 37 and 39

268 Ibid. p. 37-38.
}

269 See for example Article 16 of the Universal Declaration of Human Rights (UDHR), Article 23 in the International Covenant on Civil and Political Rights (ICCPR), Article 16 the Convention on the Elimination of all Forms of Discrimination Against Women (CEDAW), and Article 1(1) in the Convention on Consent to Marriage, Minimum age for Marriage and Registration for Marriage.

270 Supra note 214.

271 Cassese (2008) p. 41. 
The accused has the right to know the case against him, both in connection with the underlying facts and the legal qualification of the offence. ${ }^{273}$ This is problematic with regard to forced marriage as an 'other inhumane act' because the residual clause is, by its very definition, unspecified. Nevertheless, in the RUF and $A R F C$ cases, ${ }^{274}$ the Prosecutor sought to include new counts of forced marriage in the indictment at respectively five and eleven months before the trials. ${ }^{275}$ Objections to including forced marriage in the indictment were raised by the defence of the three accused in the $A R F C$ and RUF cases, on the ground that they were "too vague, imprecisely defined, did not comply with the principles of specificity or legality". ${ }^{276}$ These objections were not explicitly addressed by the Trial Chamber in the Decision on Prosecution Request for Leave to Amend the Indictment. ${ }^{277}$

It has been argued that the requirement of specificity is "still far from being fully applicable in international law, which still includes many rules that are loose in their scope." 278 In practice, most international crimes are not well defined, nor are their elements made explicit. Common international crimes have, however, been discussed and specified through case law, a process through which the elements of those crimes have crystallized. ${ }^{279}$ As regards to the crime of forced marriage, this was not the case at the SCSL because forced marriage was, at that point, a brand new crime. Therefore, it is evident that the Chamber should have paid greater attention to the specificity objections raised by the defence.

Another consideration is that a crime cannot be too specific, either. International tribunals handle cases of great complexity, thus the definitions cannot be too rigid. For example, when discussing 'conjugal association' in ICL, Oosterveld argues that it needs to be "flexible and

272 Ibid.

273 Thompson (2014) p. 220.

274 Prosecutor v. Sesay et al. and Prosecutor v. Brima et al.

275 Thompson (2014) p. 216.

276 Ibid.

277 Prosecutor v. Brima et al. TC Decision on Prosecution Request for Leave to Amend the Indictment para. 27. This decision was almost identical to the decision in Prosecutor v. Sesay et al.

278 Cassese (2008) p. 41.

279 For example rape as a crime against humanity has evolved through the following cases: Prosecutor $v$. Akayesu, Prosecutor v. Furundžija and Prosecutor v. Kunarac et al. 
wide, so as to adapt to the context and to capture different scenarios". ${ }^{280}$ Forced marriage can manifest itself in many different ways, as outlined above, and a "one fits all" definition to cover the atrocities in Cambodia, Uganda and Sierra Leone (and future scenarios) is difficult to create. However, the principle of legality, particularly foreseeability, prevents applying a very flexible definition - due to the risk of violating the accused's inherent right to a fair trial.

\subsection{Non-retroactivity}

The element of non-retroactivity is embedded in Article 15 of the ICCPR, ${ }^{281}$ according to which "No one shall be held guilty of any criminal offence on account of any act or omission which did not constitute a criminal offence, under national or international law, at the time when it was committed." This entails that forced marriage had to be criminalized in international law at the time when the conduct took place. The examination of the existence of a crime requires recourse to the legal sources set out in Article 38(1) ICJ Statute. ${ }^{282}$

Goodfellow has raised concerns about the breach of the principle of non-retroactivity by the AFRC Appeals Chamber. ${ }^{283}$ He noted that forced marriage was not a criminal offence at the time of the conduct and that therefore the Chamber offended the principle. ${ }^{284}$ If one presupposes that the specific inhumane act had to be criminalized, Goodfellow is correct in his observation. The consideration of foreseeability for the perpetrator speaks in favour of this view. On the other hand, if the assessment is whether 'other inhumane acts' per se were criminalized, the principle of non-retroactivity is clearly not violated because of the customary international law status of the crime of 'other inhumane acts'. ${ }^{285}$

It will be interesting to see how the ECCC Chamber in case 002/2 will handle this issue, because the temporal jurisdiction of the ECCC is limited to the period from 17 April 1975 until 6 January 1979. ${ }^{286}$ Thus, it will be difficult for the Court to avoid the question of retroactivity.

\footnotetext{
280 Oosterveld (2012) p. 23.

281 Also stated in Article 24 Rome Statute.

282 Cryer et al. (2014) p. 8.

283 Prosecutor v. Brima et al.

284 Goodfellow (2011) p. 866.

285 Prosecutor v. Stakić AJ para. 315.

286 Article 1 ECCC law.
} 


\subsection{Prohibition on analogy}

The ban on analogy "prohibits international courts from extending the scope and purpose of a criminal rule to a matter that is unregulated by law". ${ }^{287}$ This prohibition of extending "the definition of a crime" by analogy is embedded in Article 22(2) of the Rome Statute. Although ICL "relies more heavily on analogy" compared to national jurisdictions, ${ }^{288}$ there exists a limit of how far an analogous interpretation can go. By prosecuting forced marriage as an 'other inhumane act', the tribunals effectively circumvent the ban on analogy, because the residual clause is intended for unnamed crimes. Thus, the judiciary must resort to the use of analogy to see if the threshold is met because the assessment of an 'other inhumane act' requires a comparative analysis of forced marriage and the other already enumerated acts. ${ }^{289}$

\subsection{The legality of forced marriage}

To date, no international criminal tribunal has held an indicted crime of an 'other inhumane act' to be in violation of the principle of nullum crimen sine lege. ${ }^{290}$ Scharf states the reason for this is that "the general category conforms to the principle". ${ }^{291}$ The above-discussed elements of the principle of legality (Part 4.2-4.5) were given little to no attention in the case law discussed in Part 2. Neither the Co-Investigative Judge in $002 / 2,{ }^{292}$ nor the Pre-Trial Chamber in Ongwen, ${ }^{293}$ discussed the legality specific to forced marriage. The AFRC Appeals Chamber stated that it agreed with the assessment made by the Prosecutor;

\footnotetext{
“The Prosecution submits that the crime charged under Count 8 is 'Other Inhumane Acts,' which forms part of customary international law, and therefore, does not violate the principle of nullum crimen sine lege. Therefore, the Prosecution submits that the only question on appeal is whether forced marriage satisfies the elements of 'Other Inhumane Acts"'. 294
}

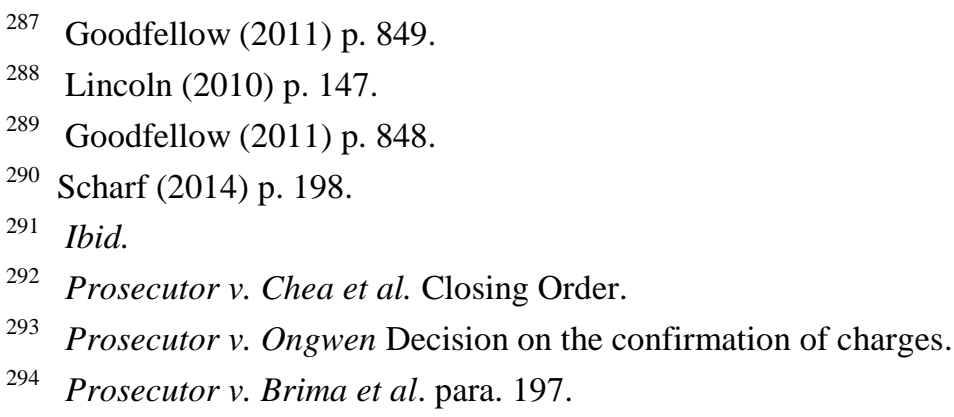


By turning to the assessment of forced marriage as an 'other inhumane act', the Chamber only implicitly handled the question of its legality. ${ }^{295}$ Thus, "there was no examination of legality specific to forced marriage that went beyond the legality of the residual category". ${ }^{296}$ This is problematic, taken into account all the different acts which can constitute an inhumane act. Is it enough to state that forced marriage is an 'other inhumane act', and therefore satisfies the principle of legality, with regard to the foreseeability for a potential perpetrator?

To conclude; views are divided on whether forced marriage as an 'other inhumane act' is in breach of the principle of legality. Goodfellow argues that the assessment made by the AFRC Appeals Chamber is "unsatisfactorily brief and an over simplification of this complex and important principle" of legality. ${ }^{297}$ Lincoln states, in general terms, that use of the residual category "to prosecute defendants for unlisted prohibitions violates" the principle of legality ${ }^{298}$ precisely because the crime is unlisted. In contrast, Scharf holds that forced marriage "does withstand nullum crimen lege scrutiny" because of the international customary status of 'other inhumane acts'. ${ }^{299}$ In sum, it is evident that further exploration of the legality of forced marriage, and not only the residual clause, is both desired and needed.

\section{The viability of forced marriage as a separate crime}

\subsection{Introductory remarks}

Previous Parts of the thesis have focused upon the evolution of forced marriage as a crime against humanity and the status of the crime today. This Part is forward-looking, asking the question: is forced marriage viable as a separate crime against humanity? Viability is in this context taken to mean "capable of living a separate existence". ${ }^{300}$ The assessment of the viability of forced marriage as a separate crime will be carried out under general reflections of the aims of ICL.

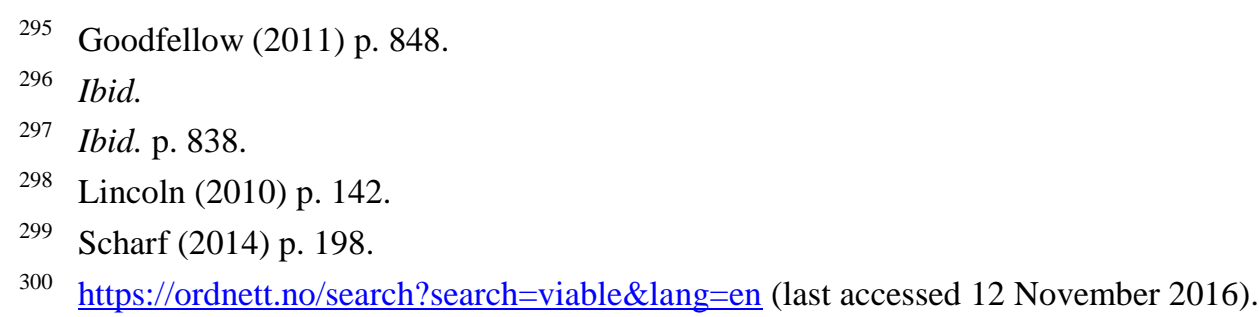


The overarching aim of ICL, as stated in the Rome Statute Preamble, is to end "impunity for the perpetrators of these crimes". ${ }^{301}$ Crimes in international law are crimes of the most serious concern to the international community, and their prosecution can serve multiple purposes such as retribution, deterrence, rehabilitation, denunciation as well as other, broader, goals. ${ }^{302}$ These aims must be balanced against each other by the tribunal in question, in order to reach a fair and just conclusion. This balancing also highlights the "complex relationship between idealism and realism" and the discussion whether the controversial judge-made law of forced marriage creates more confusion than good. ${ }^{303}$ The tension- and perhaps confusion- between de lege lata and de lege ferenda considerations have been particularly prevalent when discussing forced marriage, as seen in the foregoing. ${ }^{304}$ Parts 5.2-5.6 are devoted to the discussion of each aim of ICL, where retribution will be handled first.

\subsection{Retribution}

Retribution can be defined as "punishment inflicted on someone as vengeance for a wrong or criminal act." $" 305$ The punishment focuses on the perpetrator itself, and manifests the "necessity of punishing those who have violated societal norms, irrespective of the possible future benefits of prosecution". ${ }^{306}$ Thus, the rationale is that if an individual has committed a crime, it is in the interest of society that the person is held accountable and punished.

Given this rationale, the violation in question must relate to something which the social environment considers as common interests or goods that should be protected. ${ }^{307}$ It has been stated that a "crime cannot be understood outside its social context". ${ }^{308}$ For example, arranged marriage is a widespread practise in the non-European culture, and is often based on local traditions. ${ }^{309}$ At the same time, it can be difficult to separate forced marriages in times of conflict from arranged marriages in peace time because of their similarities; often, in arranged mar-

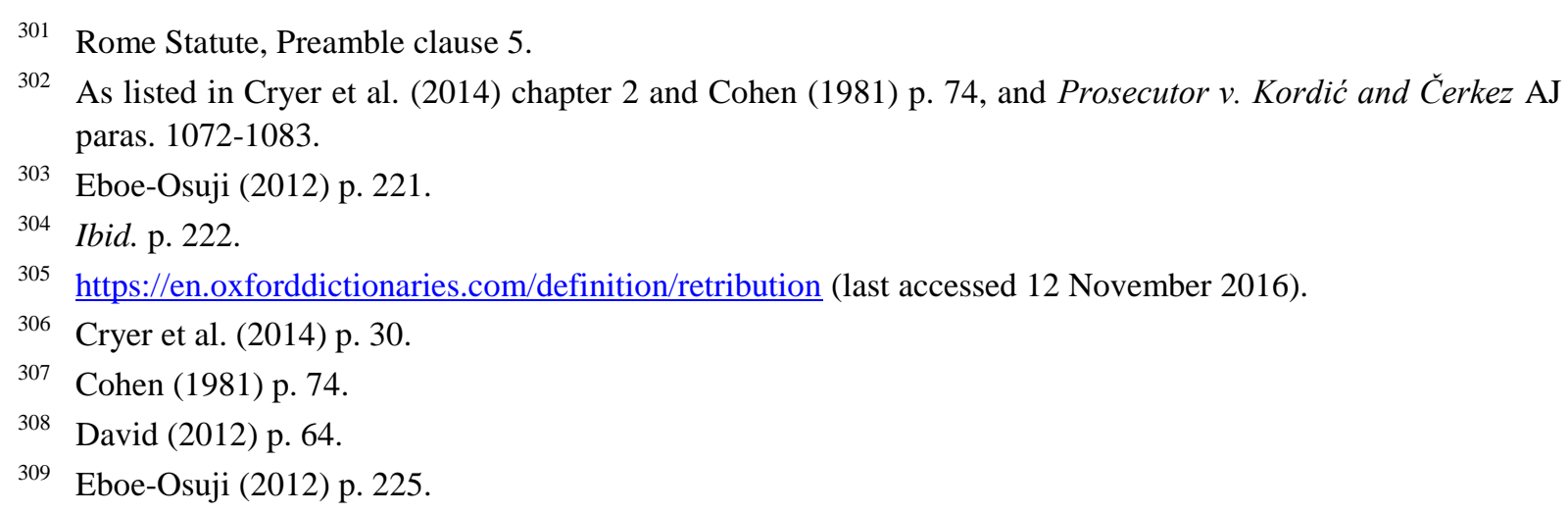


riages, the consent of one (or both) of the spouses is absent. ${ }^{310}$ It could be difficult to argue for punishing a perpetrator for committing forced marriage, when the distinction between forced and arranged marriages is blurry. ${ }^{311}$ Thus, it can be questioned whether forced marriages violate the common interest of the social environment, since arranged marriages are considered a normal practice in many societies. On the other hand, there is no doubt that forced marriages are experienced as horrible by the many women and men trapped in those marriages, nor that they inflict great suffering. Most societies regard marriage as an important institution, whereby the spouses give consent to enter into a family unit and to undertake specific rights and responsibilities. ${ }^{312}$ These aspects are reflected in Article 23 of the ICCPR, which has been ratified by most of the states in the world. The latter consideration reaffirms the idea that forced marriages violate common interests.

Forced marriages violate family structures and "demean and distort the institution of marriage itself". ${ }^{313}$ The forced conjugal association can be used to justify the horrible acts accompanied by these marriages, such as rape, forced pregnancy, torture etc. At the same time, the institution of marriage in peace time can be very different to how marriages manifests themselves in times of conflict. A characteristic common to conflict situations is that families are torn apart and family members are separated. Such consequences are normal and as such are not unique for the crime of forced marriage. Despite the fact that conflicts often lead to the dispersion of families, forced marriages in addition to entailing such consequences also have additional elements that manifest the severity of the crime.

Another consideration is whether a new offence of forced marriage is necessary in ICL. As seen from the discussion above, the constituent acts of forced marriage, such as rape, sexual enslavement, torture and forced labour, are already recognized as crimes against humanity. Is it therefore necessary to use judicial resources to prosecute and define a new crime against humanity, if the perpetrator can in any case be held accountable for all these elements separately ${ }^{314}$ Will the aim of retribution be fulfilled if the constituent crimes are adequately pros-

\footnotetext{
310 Supra note 24.

311 Some countries do make a distinction between the two in domestic law; for example the UK http://www.bbc.co.uk/ethics/forcedmarriage/ (last accessed 12 November 2016).

312 Scharf (2014) p. 200.

313 Ibid. p. 193.

314 Scharf and Mattler (2005) p. 15.
} 
ecuted? The answer to these questions must be answered in the negative. As pointed out throughout the thesis, forced marriage is more than the sum of its parts, and the additional suffering of the forced conjugal aspect is not rectified in only prosecuting the constituent acts separately.

Despite the similarities between forced marriage and arranged marriages, and bearing in mind the tendency to break-up of families in times of armed conflict, it must be concluded that forced marriage is "unique enough to warrant independent prosecution". 315 The ways in which forced marriages are manifested are a breach of common interests and thus the perpetrators deserve punishment for committing the crime.

\subsection{Deterrence}

Deterrence can be understood as "the action of discouraging an action or event through instilling doubt or fear of the consequences". ${ }^{316}$ Prosecution is used as a means of preventing new violations from being committed and focuses on "future-related benefits". ${ }^{317}$ Deterrence has a two-fold aim: firstly, to deter an individual from re-offending, and secondly, to deter a group or society as a whole. ${ }^{318}$

For individual deterrence, sentencing is the main act taken to discourage the person from committing the same crime again. ${ }^{319}$ Furthermore, the knowledge that this kind of conduct (forced marriage) could lead to future prosecution might have an individual deterrent effect. The following will focus on general deterrence, namely that "the attempt, through a sentence handed out to a particular offender, to deter others from engaging in the similar conduct". 320

It follows from the definition of deterrence that deterrence is a consequence of the effective prosecution of a particular crime. ${ }^{321}$ This requires two things: i) there must be an effective prosecution, and ii) a particular crime.

\footnotetext{
Ibid. p. 21.

316 https://en.oxforddictionaries.com/definition/deterrence (last accessed 12 November 2016).

317 Cryer et al. (2014) p. 32.

318 Cohen (1981) p. 75.

319 Prosecutor v. Kordić and Čerkez AJ para. 1077.

320 Cohen (1981) p. 76.

321 See Rome Statute Preamble, para. 5.
} 
Forced marriage was first indicted as a separate crime in the AFRC and $R U F$ cases in 2004, and has subsequently been included in the indictment in cases $002 / 2$ and Ongwen. ${ }^{322}$ To date, only three individuals have been convicted of forced marriage at the international level. ${ }^{323}$ For deterrence to be effective, it "demands near certainty of apprehension and conviction". 324 Based on this, it can be argued that the prosecution of this new crime has not been effective, compared to the amount of international cases that have been prosecuted since the AFRC and $R U F$ cases. At the same time, the practice of forced marriage might not have been prevalent in the respective situations and cases being prosecuted.

For forced marriage to have a general deterrent effect, the crime has to be defined properly. The potential perpetrator must have knowledge that the act is in fact a recognized crime, in order to be discouraged from committing the criminal act. Although the forceful imposition of conjugal association is prohibited in human rights law, it is not a given that it gives rise to individual criminal responsibility, cf. the discussion in Part 1-2. It is to be hoped that the ongoing cases ${ }^{325}$ will contribute to the affirmation of a clear definition.

The author would argue that the prosecution of forced marriage at the international level, as of now, has had little or no deterrent effect. Forced marriage in times of conflict is prevalent in many places around the world, ${ }^{326}$ and a common objection to placing too much weight on to the objective of deterrence is that it treats "people as rational calculators, who carefully weigh up the costs and benefits of their actions, and this does not reflect the reality of the decisionmaking that often precedes decisions to commit crimes". 327 Thus, even effective prosecution does not necessarily lead to more deterrence. ${ }^{328}$

In sum, it is too early in the development of the crime of forced marriage to state that it fulfills the aim of deterrence. At the same time, if more individuals are prosecuted for this newly recognized crime, the chances are that the deterrent effect will increase. The upcoming Ongwen

\footnotetext{
322 See analysis of these cases in Parts 2.2-2.4.

323 The three individuals in the Prosecutor $v$. Sesay et al. (RUF) case at SCSL are the only perpetrators who have been convicted for forced marriage.

324 Cohen (1981) p. 77.

325 Prosecutor v. Chea et al. and Prosecutor v. Ongwen.

326 Supra note 11 and 12.

327 Cryer et al. (2014) p. 32.

328 Ibid. p. 34.
} 
trial is a step in the right direction as the ICC is a permanent court and bears great influence on the prosecution of international crimes.

\subsection{Rehabilitation}

The point of rehabilitation is the "reintegration of the offender into society". ${ }^{329}$ This objective has not gained much support in ICL, mainly because the view is that these perpetrators cannot be rehabilitated back to normal life after having committed atrocities. ${ }^{330}$ There are not many cases at international tribunals where rehabilitation has been explicitly mentioned as a mitigating factor. The Erdemovic case at the ICTY was one. The accused was a 23 years old soldier who took part in a firing squad. Erdemović plead guilty to killing about 70 persons as ordered by his superiors. As a mitigating factor the Trial Chamber stated that "his circumstances and character (...) indicate that he is reformable and should be given a second chance to start his life afresh upon release". 331

Although rehabilitation is a noble goal for any criminal justice system, it is difficult to place much weight on this consideration when assessing a case. It would be very optimistic to think that the perpetrators, who forced individuals into marriages, as discussed in Part 2, would be able to rehabilitate into society. For example, many of the rebels in the AFRC and RUF in Sierra Leone, and the LRA in Northern Uganda, were abducted as children and do not know any other reality than the rebel group to which they belong. ${ }^{332}$ Turning the perpetrators away from that reality, namely of criminalities and hostilities, could be argued to be a difficult task.

\subsection{Denunciation/education}

Denunciation, meaning "public condemnation of someone or something", ${ }^{333}$ has received great support in ICL. ${ }^{334}$ By prosecuting international crimes, the international community makes it "abundantly clear that the international legal system is implemented and en-

\footnotetext{
329 Prosecutor v. Kordić and Čerkez AJ para. 1079.

330 Cryer et al. (2014) p. 35.

331 Prosecutor v Erdemović, TJ para. 16.

332 https://www.hrw.org/news/2000/05/31/sierra-leone-rebels-forcefully-recruit-child-soldiers (last accessed 12 November 2016) and Carlson and Mazurana (2008) p. 16.

333 https://en.oxforddictionaries.com/definition/denunciation (last accessed 12 November 2016).

334 Cryer et al. (2014) p. 36.
} 
forced". ${ }^{335}$ In turn, prosecution internalizes the wrongdoing before the offender, victims and society as a whole, ${ }^{336}$ creating "trust in and respect for the developing system of international justice". 337

Prosecuting forced marriage at international courts will lead to increased awareness of the crime of forced marriage. International trials often engage several actors, inter alia, local activists, victims, witnesses, and affected communities, leading to greater discussion and awareness of the crime. Thus, if forced marriage is not tried, "the international community sends a message that these acts are acceptable as long as they are done under the guise of 'marriage" ". ${ }^{338}$ Even more so, the general deterrent effect might diminish, creating a loophole that affords perpetrators impunity.

\subsection{Other, broader goals}

Vindication of the rights of the victims: Convicting perpetrators of forced marriage enables the victims to see justice being done. This in turn, often makes it easier for the victims to gain closure and move on. ${ }^{339}$ Furthermore, prosecuting forced marriage increases the recognition of the special suffering that these victims undergo. On the other hand, there is a risk that a trial rips open old wounds, and in fact does not contribute to closure, when prosecuting forced marriage. ${ }^{340}$ Another aspect is that some persons being forced into marriages in Cambodia did not feel victimized, and stayed in the marriage after the Khmer Rouge regime fell. As one "victim" stated: "If it is a happy marriage, how can it be forced?"341

Record history: When a case is brought before an international court, massive amounts of evidence from the conflict/situation is gathered and analysed. This evidence, when discussed and perhaps contested by one of the parties, helps to shed light on the factual circumstances in which the victims found themselves under these marriages. ${ }^{342}$ For example, the policy of

\footnotetext{
335 Prosecutor v. Kordić and Čerkez AJ para. 1080.

336 Ibid.

337 Prosecutor v. Kupreškić et al., TJ para. 848.

338 Kalra (2001) p. 204.

339 Cryer et al. (2014) p. 37.

340 Lilja (2013) p. 62.

341 Ibid. p. 65.

342 Ibid.
} 
forced marriages during the Khmer Rouge regime in Cambodia has "not been subject to much study" until now. ${ }^{343}$ Thousands of victims of forced marriage in Cambodia did not speak of this practice and kept their marriages a secret. Now, the victims are given a change to understand the trauma they underwent and to record their stories. ${ }^{344}$ Furthermore, as Ye puts it: "more than any other crime, cases of forced marriage highlight the link between the past and the present, individual and family, and individual survivors and the whole of post-conflict society". ${ }^{345}$ If forced marriage is not prosecuted as the unique crime that it is, these positive aspects will be lost or severely diminished.

Contribution to post-conflict reconciliation: Empirical research has shown that the "ICTY and the ICTR have significantly contributed to peace building in postwar societies, as well as to introducing criminal accountability into the culture of international relations". ${ }^{346}$ One of the ways prosecuting forced marriage might help with post-conflict reconciliation is that it might increase awareness of this practice in the local communities. For example, a great number of the rebel wives in RUF and AFRC had the letters of the groups branded onto their chest. ${ }^{347}$ This led to many of the wives being suspected of being rebels, resulting in them being shunned by their communities or even killed. ${ }^{348}$ By recognizing the coercive circumstances of forced marriage, and raising awareness in communities, reconciliation might be more easily obtained.

Furthermore, criminalizing forced marriage internationally may contribute to improving national legislation in the affected country. This could in turn "serve the larger goal of effecting a reconciliation between the offender and his victim". ${ }^{349}$ For example, in 2007, after the trials in Sierra Leone had begun, new national legislation collectively entitled "Gender Bills" was passed. These bills included, inter alia, the "Domestic Violence Act [and] the Registration of

\footnotetext{
343 Ye (2011) p. 472.

344 Ibid. p. 473.

345 Ibid. p. 469.

346 Akhavan (2001) p. 9.

347 Palmer (2009) p. 135.

348 Ibid.

349 Cohen (1981) p. 90.
} 
Customary Marriages and Divorce Act" 350 which introduced "a minimum age of eighteen years of age and requires consent of both parties for such marriages to be valid". 351

\subsection{Concluding remarks on the viability of forced marriage as a separate crime}

Is forced marriage viable as a separate crime against humanity (capable of living a separate existence) in the context of the general aims of ICL? This question will be assessed through a cost/benefit analysis: $:^{352} \mathrm{~A}$ cost/benefit analysis requires assessing whether the input (the resources that have and are being put into defining, criminalizing and prosecuting forced marriage as a separate crime against humanity) generates the desirable judicial outcomes (the fulfillment of the general aims of ICL).

It must be highlighted that the foregoing discussion in Part 5 has, to a large extent, been forward looking, and is partly based on speculation. It is evident that more empirical research is needed to address and assess the question of the viability of forced marriage as a separate crime, especially with regard to establishing a link of causation between inputs and outcomes. $^{353}$

It is no secret that many international tribunals are under financial restraints, and that therefore selecting which cases, perpetrators and crimes to prosecute must be done with great care and pragmatism. ${ }^{354}$ For example, Kalra points out that "the reasons for not prosecuting forced marriages [in Rwanda] are unknown but may be due to the OTP's lack of resources". ${ }^{355}$ Justice at the international level is slow. If new crimes are to be created and prosecuted, the desired output of the prosecution should be perceived as high. One could ask whether it would be more cost and time efficient to prosecute the already enumerated sexual- and gender-based crimes listed in the Tribunals' statute, for example in Article 7 (1) (g) in the Rome Statute, where the crimes are already recognized and are elaborated on in ICC Elements of Crime.

\footnotetext{
350 Palmer (2009) p. 155.

351 Ibid. p. 156.

352 Shany (2012) p. 248.

353 Ibid. p. 254.

354 Mionki (2010) p. 306.

355 Kalra (2001) p. 203.
} 
Nonetheless, that might not be sufficient for the victims and affected societies of these horrible crimes to be able to reconcile with the past.

The question remains: is forced marriage a viable crime against humanity? On the one hand, "recognising the challenges of, and obstacles to, the effective investigation and prosecution of sexual and gender-based crimes" has been a core strategic aim at the ICC since $2014 .{ }^{356}$ This affirms the wish and will of the Prosecutor to use resources for this purpose. On the other hand, good intentions do not necessarily lead to fruitful outcomes. And outcomes do count. ${ }^{357}$ The analysis and discussion in Part 2-4 highlighted some of the difficulties in identifying and prosecuting forced marriage. Handling a new crime demands a lot of judicial resources - and it can be questioned whether prosecuting forced marriage is being done at the expense of prosecuting other crimes. At the same time, many of the overarching aims of ICL speak in favor of the viability of forced marriage as a separate crime. Again, development is slow at the international level, and the tribunals, in particular the ICC, "should be given time during which to develop its operations for its effects to be assessed." 358

In the opinion of the author, forced marriage is a viable crime, i.e. capable of living a separate existence. Thus, the goal should be to continue the prosecution of this crime. However, further research is called for, in order to assess whether the desired outcomes match the input. Thus, having a realistic approach as to what the law is, and should be, is paramount.

356 ICC OTP Policy Paper on Sexual and Gender-Based Crimes (2014) p. 5.

357 Schiff (2012) p. 76.

358 Ibid. 


\section{Table of References}

\section{International treaties and conventions}

$\mathrm{CCM}$

CEDAW

ECCC Agreement

ECCC law

ICJ

ICCPR

ICTY Statute

ICTR Statute

SCSL Statute

Nuremberg Charter

Rome Statute

UDHR
Convention on Consent to Marriage, Minimum Age for Marriage and Registration for Marriages, 7 November 1962, 986 UNTS 939 (entered into force 1964).

Convention on the Elimination of all Forms of Discrimination Against Women, 18 December 1979, 1249 UNTS 13 (Registered ex officio 3 September 1981).

Agreement Between The United Nations and the Royal Government of Cambodia Concerning the Prosecution under Cambodian Law of Crimes Committed During the Period of Democratic Kampuchea, signed June 6 2003, entered into force 29 April 2005, (draft Agreement annexed to GA Res. 57/228B).

Law on the Establishment of the Extraordinary Chambers in the Courts of Cambodia for the Prosecution of Crimes Committed during the period of Democratic Kampuchea, dated 27 October 2004.

Statute for the International Court of Justice (ICJ) (adopted 26 June 1945, entered into force 24 October 1945).

International Covenant on Civil and Political Rights 1966, 999 UNTS.

Statute of the International Criminal Tribunal for the Former Yugoslavia, May 23rd 1993, Annexed to SC Res. 827(1993) (with later amendments).

Statute of the International Criminal Tribunal for Rwanda, November 8th 1994, Annexed to SC Res. 955(1994) (with later amendments).

Statute of the Special Court for Sierra Leone, 16 January 2002.

Agreement for the Prosecution and Punishment of the Major War Criminals of the European Axis Powers and Charter of the International Military Tribunal, 82 UNTS 279.

Rome Statute of the International Criminal Court (adopted 17 July 1998, entered into force 1 July 2002) 2187 UNTS 38544.

Universal Declaration of Human Rights, GA Res. 217 A (III) 1948. 


\section{Case law}

International Criminal Tribunal for Rwanda

Prosecutor v. Akayesu ICTR-96-4, Trial judgment 2 September 1998

International Criminal Tribunal for the Former Yugoslavia

Prosecutor v. Erdemović

IT-96-22, Trial judgment: Sentencing judgment 5 March 1998.

Prosecutor v. Furundžija

IT-95-17/1, Trial judgment 10 December 1998, Appeal judgment 21 July 2000.

Prosecutor v. Kordić and Čerkez IT-95-14/2, Appeals judgment 17 December 2004.

Prosecutor v. Kunarac et al.

IT-96-23 \& 23/1, Trial judgment 22 February 2001.

Prosecutor v. Kupreškić et al.

IT-95-16, Trial judgment 14 January 2000.

Prosecutor v. Kvočka et al.

IT-98-30/1, Trial judgment 2 November 2001.

Prosecutor v. Stakić

IT-97-24-A, Appeals judgment 22 March 2006.

Special Court for Sierra Leone

Prosecutor v. Brima et al.

SCSL-2004-16,

Appeals judgment 22 February 2008.

Trial judgment 20 June 2007.

Trial Chamber, Prosecution Filing of Expert Report Pursuant to Rule 94(bis) and Decision on Prosecution Request for Leave to Call an Expert Witness (Prosecution Expert Bangura) 8 August 2005.

Trial Chamber Decision on Prosecution request for Leave to Amend the Indictment, 6 May 2004.

Prosecutor v. Norman et al. SCSL-2004-14, Trial judgment .

Prosecutor v. Sesay et al. SCSL-2004-15, Trial judgment 2 March 2009, Appeals judgment 26 October 2009.

Prosecutor v. Taylor. SCSL-2003-01, Trial judgment 18 May 2002. 


\section{Extraordinary Chambers for the Courts of Cambodia}

Prosecutorv. Chea et al.

International Criminal Court

Prosecutor v. Bemba

Prosecutor v. Katanga

Prosecutor v. Lubanga

Prosecutor v. Ongwen
Case 002/19-09-2007-ECCC.

Request for Leave to Submit Amicus Curiae Brief for Forced Marriage ECCC, 14 June 2016, filed to the Trial Chamber.

Co-Investigating Judges, Closing Order, 15 September 2010.

Co-Investigating Judges, Order on Request for Investigative Action Concerning Forced Marriage and Forced Sexual Relations, 18 December 2009. Co-Lawyers for the Civil Parties' Fourth Investigative Request, 4 December 2009.

ICC-01/05-01/08.

ICC-01/04-01/07-717.

Opening Statement by the Prosecutor of ICC01/04-01/07-T-80-ENG.

Pre-Trial Chamber, Decision on the Confirmation of Charges, 30 September 2008.

ICC-01/04-01/06.

ICC-02/04-01/15.

Defence Brief for the Confirmation of Charges Hearing, filed on 18 January 2016 as ICC-02/0401/15-404-Conf.

Pre-Trial Chamber, Decision on the Confirmation of Charges, 23 March 2016. 


\section{Other court documents and policy papers}

ECCC IR

ICC Elements of Crimes

ICC RPE

SCSL RPE
ECCC Internal Rules, adopted on 12 June 2007

Elements of the Crimes International Criminal Court

https://www.icc-cpi.int/NR/rdonlyres/336923D8-A6AD-

40ECAD7B-45BF9DE73D56/0/ElementsOfCrimesEng.pdf

Rules of Procedure and Evidence https://www.icc-

cpi.int/iccdocs/pids/legal-texts/rulesprocedureevidenceeng.pdf

ICC policy paper S\&GBV ICC Policy Paper on Sexual and Gender-Based Crimes, June 2014 https://www.icc-cpi.int/iccdocs/otp/OTP-Policy-Paper-onSexual-and-Gender-Based-Crimes--June-2014.pdf

SCSL Rules of Procedure and Evidence, adopted on 16 January 2002 .

\section{Books}

Cassese, Antonio, International Criminal Law, 2. ed., 2008.

Cryer, Robert, Håkan Friman, Darryl Robinson, Elizabeth Wilmshurst, An Introduction to International Criminal Law and Procedure, 3. ed., 2014.

Eboe-Osuji, Chile, International Law and Sexual Violence in Armed Conflicts, International Humanitarian Law Series Vol. 35, 2012.

Lilja, Mona, Resisting Gendered Norms: Civil Society, the Juridical and Political Space in Cambodia, 2013.

Mibenge, Chiseche Salome, Sex and International Tribunals: The Erasure of Gender from the War Narrative, 2013.

Schabas, William A., The International Criminal Court: A Commentary on the Rome Statute, 2010.

Werle, Gerhard and Florian Jessberger, Principles of international criminal law, 3. ed., 2014. 


\section{Chapters}

Askin, Kelly D., "Crimes against women under international criminal law", in: Research Handbook on International Criminal Law, Bartram S. Brown (ed.), 2011, p. 84-113.

Chinkin, Christine, "Women: The Forgotten Victims of Armed Conflict?", in: The Changing Face of Conflict and the Efficacy of International Humanitarian Law, Helen Durham and Timothy L.H. McCormack (eds.), 1999, p. 23-44.

da Silva, Clare, "The hybrid experience of the Special Court for Sierra Leone", in: Research Handbook on International Criminal Law, Bartram S. Brown (ed.), 2011, p. 232-258.

deGuzman, Margaret M., "Crimes against humanity”, in: Research Handbook on International Criminal Law, Bartram S. Brown (ed.), 2011, p. 62-83.

Mionki, Judy, "The Evolving Trend to Criminalize Forced Marriage in International Criminal Law", in: Hague Yearbook of International Law, Nikos Lavranos et al. (eds.), Vol. 23 2010, p. 269-310.

Oosterveld, Valerie, "Evaluating the Special Court for Sierra Leone's Gender Jurisprudence”, in: The Sierra Leone Special Court and Its Legacy: The Impact for Africa and International Criminal Law, Charles Chernor Jalloh (ed.), 2014, p. 234-259.

Scharf, Michael P., "Forced Marriage as a Separate Crime against Humanity", in: The Sierra Leone Special Court and Its Legacy: The Impact for Africa and International Criminal Law, Charles Chernor Jalloh (ed.), 2014, p. 193-214.

Thompson, Sidney, "Forced Marriage at the Special Court for Sierra Leone: Questions of Jurisdiction, Legality, Specificity, and Consistency", in: The Sierra Leone Special Court and Its Legacy: The Impact for Africa and International Criminal Law, Charles Chernor Jalloh (ed.), 2014, p. 215-233. 


\section{Journal articles}

Akhavan, Payam, "Beyond Impunity: Can International Criminal Justice Prevent Future Atrocities?", The American Journal of International Law, Vol. 95 (1) January (2001) p. 7-31.

Bunting, Annie, “'Forced Marriage' in Conflict Situations: Researching and Prosecuting Old Harms and New Crimes", The Canadian Journal of Human Rights, Vol. 1(1) Spring (2012) p. $165-185$.

Christensen, Cameron, "Forced Marriage at the Cambodian Crossroads: ECCC Can Develop a New Crime Against Humanity", Brigham Young University Law Review, Vol. 6 (2015) p. $1825-1845$.

Cohen, Stanley A., "An Introduction to the Theory, Justifications and Modern Manifestations of Criminal Punishment”, McGill Law Journal, Vol. 27(1) (1981), p. 73-91.

David, Bogdan, "The Place of Punishment within the Criminal Justice System", Contemporary Readings in Law and Social Justice, Vol. 4(1) January (2012), p. 63-68.

Elander, Maria, "Prosecuting the Khmer Rouge Marriages", Australian Feminist Law Journal, Vol. 42(1) (2016) p. 163-175.

Frulli, Micaela, "Advancing International Criminal Law: The Special Court for Sierra Leone Recognizes Forced Marriage as a 'New' Crime against Humanity”, Journal of International Criminal Justice, Vol. 6(5) (2008), p. 1033-1042.

Gekker, Elena, "Rape, Sexual Slavery, and Forced Marriage at the International Criminal Court: How Katanga Utilizes a Ten-Year-Old Rule but Overlooks New Jurisprudence”, Hastings Women's Law Journal, Vol. 25(1) (2014) p. 105-133.

Gong-Gershowitz, Jennifer, “Forced Marriage: A 'New' Crime Against Humanity?”, Northwestern Journal of International Human Rights, Vol 8 (1) (2009), p. 53-75. 
Goodfellow, Nicholas Azadi, “The Miscategorization of 'Forced Marriage' as a Crime against Humanity by the Special Court for Sierra Leone”, International Criminal Law Review, Vol. 11(5) (2011), p. 831-867.

Haenen, Iris, "The Parameters of Enslavement and the Act of Forced Marriage", International Criminal Law Review, Vol 13(4) (2013) p. 895-915.

Jain, Neha, "Forced Marriage as a Crime against Humanity: Problems of Definition and Prosecution”, Journal of International Criminal Justice, Vol. 6(5) (2008), p. 1013-1032.

Kalra, Monika Satya, "Forced Marriage: Rwanda's Secret Revealed”, U.C. Davis Journal of International Law \& Policy, Vol. 7(2) Spring (2001), p. 197-221.

Lincoln, Jennifer, "Nullum crimen sine lege in International Criminal Tribunal Jurisprudence: The problem of the residual category of crime", Eyes on the International Criminal Court, Vol. 7(1) January (2010), p.137-155.

Nguyen, Frances, "Untangling Sex, Marriage, and Other Criminalities in Forced Marriage", Goettingen Journal of International Law, Vol. 6(1) (2014), p. 13-45.

O'Brien, Melanie, “'Don't kill them, let's choose them as wives': the development of the crimes of forced marriage, sexual slavery and enforced prostitution in international criminal law", The International Journal of Human Rights, Vol. 20(3) (2016), p. 386-406.

Oosterveld, Valerie, “The Special Court for Sierra Leone, Child Soldiers, and Forced Marriage: Providing Clarity or Confusion?", The Canadian Yearbook of International Law, Vol. 45 Annual (2007), p. 131-172.

Oosterveld, Valerie, "The Gender Jurisprudence of the Special Court for Sierra Leone: Progress in the Revolutionary United Front Judgments", Cornell International Law Journal, Vol. 44(1) (2011a), p. 49-74. 
Oosterveld, Valerie, "Forced Marriage and the Special Court for Sierra Leone: Legal Advances and Conceptual Difficulties", Journal of International Humanitarian Legal Studies, Vol. 2(1) (2011b), p. 127-158.

Oosterveld, Valerie, "Gender and the Charles Taylor case at the Special Court for Sierra Leone", William \& Mary Journal of Women and the Law, Vol. 19(1) Fall (2012), p. 7-33.

O'Sullivan, Carmel, "Dying for the Bonds of Marriage: Forced Marriages as a Weapon of Genocide”, Hastings Women's Law Journal, Vol. 22(2) Summer (2011), p. 271-294.

Palmer, Amy, "An Evolutionary Analysis of Gender-Based War Crimes and the Continued Tolerance of "Forced Marriage", Northwestern Journal of International Human Rights, Vol. 7(1) (2009) p. 133-159.

Scharf, Michael P. and Suzanne Mattler, "Forced Marriage: Exploring the Viability of the Special Court for Sierra Leone's New Crime Against Humanity", Case Research Paper Series in Legal Studies Working Paper, No. 05-35, October (2005), p. 1-24, <ssrn.com/abstract $=824291>$.

Schiff, Benjamin, “The ICC's Potential for Doing Bad When Pursuing Good” (Essay), Ethics \& International Affairs, Vol. 26(1) Spring (2012), p. 73-81.

Shany, Yuval, "Assessing the Effectiveness of International Courts: A Goal-Based Approach”, American Journal of International Law, Vol. 106(2) 01 April (2012), p. 225-270.

Toy-Cronin, Bridgette A., "What is Forced Marriage? Towards a Definition of Forced Marriage as a Crime against Humanity", Columbia Journal of Gender and Law, Vol. 19(2) (2010), p. 539-590.

Ye, Beini, "Forced Marriages as Mirrors of Cambodian Conflict Transformation", Peace Review, Vol. 23(4) 01 October (2011), p. 469-475. 


\section{Miscellaneous}

Carlson, Khristopher, and Dylan Mazurana, "Forced Marriage within the Lord's Resistance Army, Uganda". (2008) http://fic.tufts.edu/publication-item/forced-marriage-with-the-lordsresistance-army-uganda/

Human Rights Watch, “We'll Kill You If You Cry: Sexual Violence in the Sierra Leone Conflict", Vol. 15, No. 1 January 2003.

http://www.hrw.org/reports/2003/sierraleone/sierleon0103.pdf

Physicians for Human Rights, "War-related Sexual Violence in Sierra Leone: A Populationbased Assessment”, (2002). https://s3.amazonaws.com/PHR_Reports/sierra-leone-sexualviolence-2002.pdf

The Commission of Women of ECOSOC, "Forced marriage of the girl child", UN Doc. E/CN.6/2008/4, 5 December 2007. https://documents-ddsny.un.org/doc/UNDOC/GEN/N07/626/97/PDF/N0762697.pdf?OpenElement

UN General Assembly, Report of the UN Secretary-General: "In Depth Study on all Forms of Violence Against Women: Report of the Secretary-General", UN Doc A/61/122/Add.1, 6 July 2006.

\section{Internet Articles}

https://www.amnesty.org/en/latest/news/2016/10/gambia-withdrawal-from-icc-adrastic-blow-to-countless-victims-globally/ (last accessed 7 November 2016).

http://www.bbc.co.uk/ethics/forcedmarriage/ (last accessed 12 November 2016). 2016).

https://www.eccc.gov.kh/en/about-eccc/introduction (last accessed 7 November 2016). https://www.eccc.gov.kh/en/articles/severance-proceedings-ordered-case-002 (last accessed 7 November 2016).

https://en.oxforddictionaries.com/definition/denunciation (last accessed 12 November 2016).

https://en.oxforddictionaries.com/definition/deterrence (last accessed 12 November 
https://en.oxforddictionaries.com/definition/retribution (last accessed 12 November 2016).

https://www.hrw.org/news/2015/04/14/iraq-isis-escapees-describe-systematic-rape (last accessed 7 November 2016).

https://www.hrw.org/news/2001/02/26/sexual-violence-within-sierra-leone-conflict (last accessed 7 November 2016).

https://www.hrw.org/world-report/2016/ending-child-marriage (last accessed 14 November 2016).

https://www.hrw.org/news/2000/05/31/sierra-leone-rebels-forcefully-recruit-childsoldiers (last accessed 12 November 2016).

https://www.icc-cpi.int/Pages/item.aspx?name=pr1088 (last accessed 7 November 2016).

https://www.icc-cpi.int/Pages/item.aspx?name=pr1216 (last accessed 7 November 2016).

https://ordnett.no/search?search=viable\&lang=en (last accessed 12 November 2016).

http://www.oxforddictionaries.com/definition/english/arranged-marriage (last accessed 7 November 2016).

https://www.washingtonpost.com/world/africa/they-were-freed-from-boko-haramsrape-camps-but-their-nightmare-isnt-over/2016/04/03/dbf2aab0-e54f-11e5-a9ce681055c7a05f_story.html (last accessed 7 November 2016). 